\title{
Bankruptcy Law and Inefficient Entitlements
}

\author{
Dr. Irit Haviv-Segal ${ }^{\dagger}$
}

TABLE OF CONTENTS

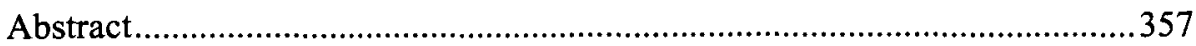

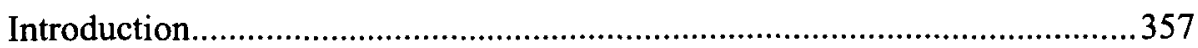

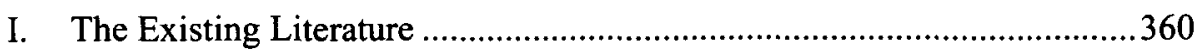

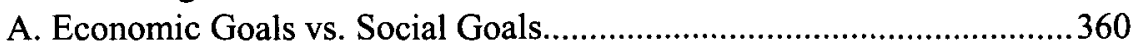

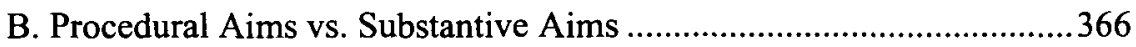

C. Micro-Economic Aims vs. Macro-Economic Aims .............................368

II. Inefficient Entitlements and Legal Coercion ...........................................370

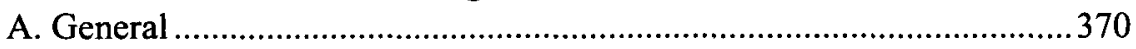

B. The Meaning and Sources of Inefficient Entitlements .........................371

C. The Failure of the Renegotiation Process............................................377

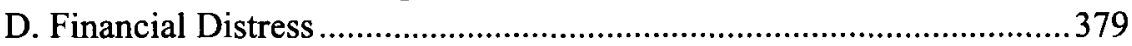

E. The Justification of Coercive Interference with Existing

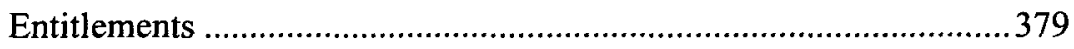

III. The Role and Content of Bankruptcy Law ............................................379

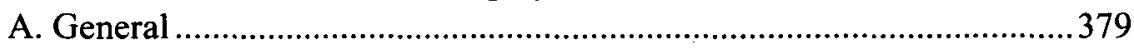

B. The Essence of Collective Collection Proceedings .............................382

IV. Concrete Arrangments of Bankruptcy Law ...............................................383

A. The Choice between Reorganization and Liquidation ..........................383

B. Obtaining New Credit in Reorganizations..........................................389

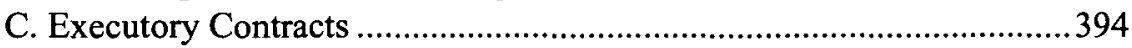

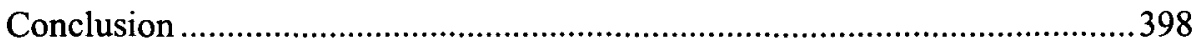

' Senior Lecturer, Tel-Aviv University, Faculty of Law. LLB, Hebrew University, 1984; LLM, Yale Law School, 1987; JSD, Yale Law School, 1989. 


\title{
Bankruptcy Law and Inefficient Entitlements
}

\author{
Dr. Irit Haviv-Segal
}

\begin{abstract}
The justification for bankruptcy law remains an open question. The literature tends to emphasize the conflict and the inability to compromise between the different normative outlooks of the insolvency law system. A deeper reflection on the existing theories of bankruptcy law reveals, however, that all theories agree that the enforcement of contractual bankruptcy arrangements maximizes aggregate efficiency. Social theories calling for increased levels of coercion and redistribution do not dispute the efficiency of enforcing prior entitlements, but rather, place an overriding premium on normative considerations of distributive justice and rehabilitation values. This Article presents a new theory of bankruptcy law that challenges this shared starting point. To be sure, the Article supports the economic analysis' focus on efficiency considerations-it calls for bankruptcy law rules that would maximize the aggregate value of the debtor's assets to his or her creditors and equity holders. Yet the analysis shows that under particular circumstances, efficiency-based considerations can support the coercive avoidance of existing entitlements, a result ordinarily advocated by the social theories. Accordingly, I will argue that the role of bankruptcy law is to provide the procedural and substantive framework for severing the debtor's economic resources from his or her inefficient liabilities. The analysis proceeds to show how the new theoretical framework explains many of the positive legal arrangements of bankruptcy law. First, it explains why courts prefer reorganization plans over liquidation proceedings. Second, it explains why the law affords special priority to post-petition creditors. Finally, it explains the arrangements regarding executory contracts.
\end{abstract}

\section{INTRODUCTION}

The justification for bankruptcy law remains an open question. The literature tends to emphasize the conflict and the inability to compromise between the different normative outlooks of the insolvency law system. ${ }^{1}$ In

1. For this ongoing debate, see generally Omer Tene, Revisiting the Creditors' Bargain: The Entitlement to the Going-Concern Surplus in Corporate Bankruptcy Reorganizations, 19 BANKR. DEV. J. 287 (2003) and the references therein; Charles W.Mooney, A Normative Theory of Bankruptcy Law: Bankruptcy as (is) Civil Procedure (U. Pa. Inst. for Law \& Econ., Research Paper No. 03-27, 2003) and the references therein; Lynn M. Lopucki, The Myth of the Residual Owner: An Empirical Study (UCLA. 
particular, the literature emphasizes the conflict between the economic perspectives that focus on the efforts to maximize the value paid to creditors in the event of insolvency, and the social perspectives that emphasize the social and rehabilitative values of the law. Naturally, the specific laws that derive from each of these perspectives differ greatly, and it appears that the compound that developed in the positive law over the years is a quasi-amalgam, lacking any clear preference towards any of the different approaches.

Contemporary theories of bankruptcy law conflict on two main issues: first, the appropriate level of justified coercion that should be involved in the bankruptcy proceedings; and second, the appropriate level of justified intervention with prior entitlements. While contemporary economic analysis of bankruptcy law calls for contractual bankruptcy arrangements, ${ }^{2}$ the social theories support a more interventionist approach to protect the "weak" parties against the losses of insolvency. ${ }^{3}$ Thus, while economic analysis challenges bankruptcy courts' coercive interference with contractual arrangements made prior to insolvency, social theories support such court-enforced redistribution schemes.

A deeper reflection on the existing theories of bankruptcy law reveals, however, that all theories agree that efficiency considerations justify the enforcement of contractual bankruptcy arrangements. All theories presume that the protection of entitlements that were formed ex ante would maximize aggregate efficiency. The enforcement of prior entitlements secures the efficient planning of credit transactions by solvent corporations. Social theories

Sch. of Law, Law \& Econ. Research Paper No. 03-11, 2003); Marshall E. Tracht, Contractual Bankruptcy Waivers: Reconciling Theory, Practice, and Law, 82 CORNELL L. REV. 301 (1997); Christopher W. Frost, Bankruptcy Redistributive Policies and the Limits of the Judicial Process, 74 N.C. L. REV. 75 (1995); Jay Lawrence Westbrook, The Control of Wealth in Bankruptcy, 82 TEX. L. REV. 795 (2004).

2. See Alan Schwartz, A Contract Theory Approach to Business Bankruptcy, 107 YALE L.J. 1807, 1851 (1998) (hereinafter, Schwartz, Contract Theory) ("This Essay's central claim is captured in a variation on a trendy slogan: Privatize bankruptcy."); Alan Schwartz, Bankruptcy Contracting Reviewed, 109 YALE L.J. 343, 343 (1999) ("If the rule against contracting for a preferred bankruptcy system were relaxed, parties would write bankruptcy contracts that would induce a borrowing firm to choose the system that would be optimal for it and its creditors were it to become insolvent."); see also Barry Adler et al., Regulating Consumer Bankruptcy: A Theoretical Inquiry, 29 J. LEGAL STUD. 585 (2000); Robert K. Rasmussen, Resolving Transnational Insolvencies through Private Ordering, 98 MiCH. L. REV. 2252 (2002); Douglas G. Baird \& Robert K. Rasmussen, The End of Bankruptcy, 55 STAN. L. REv. 751 (2002).

3. See generally Susan Block-Lieb, The Logic and Limits of Contract Bankruptcy, 2001 U. ILL. L. REV. 503 (2001); Susan Block-Lieb, The Politics of Privatizing Business Bankruptcy Law, 74 AM. BANKR. L.J. 77 (2000); Charles J. Tabb, Of Contractarians and Bankruptcy Reform: A Skeptical View, 12 AM. BANKr. INST. L. Rev. 259 (2004); Robert B. Chapman, Missing Persons: Social Science and Accounting for Race, Gender, Class, and Marriage in Bankruptcy, 76 AM. BANKR. L.J. 347 (2002); Elizabeth Warren, Bankruptcy Policy, 54 U. CHI. L. REV. 775 (1987); Elizabeth Warren \& Jay Lawrence Westbrook, Financial Characteristics of Businesses in Bankruptcy, 73 AM. BANKR. L.J. 499 (1998); Donald R. Korobkin, Bankruptcy Law, Ritual, and Performance, 103 COLUM. L. REV. 2124 (2003); Donald R. Korobkin, Rehabilitating Values: A Jurisprudence of Bankruptcy, 91 COLUM. L. REV. 717 (1991); Donald R. Korobkin, The Role of Normative Theory in Bankruptcy Debates, 82 Iowa L. REV. 75 (1996). 
calling for increased levels of coercion and redistribution do not dispute the efficiency of enforcing prior entitlements, but rather, place an overriding premium on normative considerations of distributive justice and rehabilitation values. ${ }^{4}$

This Article presents a new theory of bankruptcy law that challenges this shared understanding. To be sure, the Article supports the economic analysis' focus on efficiency considerations-it calls for bankruptcy law rules that would maximize the aggregate value of the debtor's assets to his or her creditors and equity holders. Yet the analysis shows that under particular circumstances, efficiency-based considerations can support the coercive avoidance of existing entitlements, a result ordinarily advocated by the social theories. Under these particular circumstances, the existing entitlements drive the business into an inefficient use of its economic resources, which in turn leads to financial distress. It would seem that rational parties should then renegotiate their contracts, and restructure the company's liabilities. However, I will point out several factors that may obstruct the renegotiation process and preclude the possibility of contractual settlement. When these factors are present, the coercive interference of the bankruptcy proceedings may become essential for shifting the company resources back to efficient business activity.

This argument will provide the framework for defining both the circumstances that should trigger the commencement of bankruptcy proceedings, and the role of bankruptcy law itself. In particular, the law must regulate the commencement of bankruptcy proceedings when the following three conditions are satisfied: first, the debtor's existing entitlements produce an inefficient use of economic resources; second, the debtor has failed in his or her attempt to restructure the existing liabilities; and third, the inefficient entitlements have lead the debtor into financial distress. If these three conditions are met, then in the absence of any legal intervention, the company would encounter a perpetually inefficient use of its economic resources, and the costs of this inefficiency would compound over time. Accordingly, I will argue that the role of bankruptcy law is to provide the procedural and substantive framework for severing the debtor's economic resources from his or her inefficient liabilities. Thus, bankruptcy proceedings inherently involve some level of coercion and redistribution.

Finally, I will show that the new theory can explain many of the positive legal arrangements of bankruptcy law. First, it explains why courts prefer reorganization plans over liquidation proceedings. Second, it explains the special priority that the law affords to post-petition investors. Finally, it provides the normative framework for the legal arrangement of executory contracts.

4. See, e.g., Susan Block-Lieb, The Politics of Privatizing Business Bankruptcy Law, supra note 3. 
Part I of the Article presents the main conflicting views concerning the role and content of bankruptcy law. Part II presents the efficiency-based justification for coercive avoidance of existing entitlements. Part III explains how bankruptcy law leads to the severance of the debtor's assets from his or her contemporary liabilities. Finally, Part IV discusses the concrete legal arrangements, and shows how positive arrangements reconcile with the above theory.

\section{THE EXISTING LITERATURE}

\section{A. Economic Goals vs. Social Goals}

The main conflict between the different approaches of bankruptcy law is the familiar one between the economic and social approaches to the law. The economic approach emphasizes the efficiency aims of the law, that is, its aims are directed toward enlarging the "aggregate pie which is to be divided."5 Social approaches emphasize the policy considerations relevant in deciding how to distribute "the aggregate pie" among the different parties. ${ }^{6}$ In the context of bankruptcy law, the economic approaches emphasize the goal of enlarging the value of the bankrupt estate, while the social perspectives focus on the appropriate distribution rules governing the creditors.

Beginning with the economic approach, it is insightful to distinguish between the earlier and later economic approaches to bankruptcy law. In the seminal 1986 work, The Logic and Limits of Bankruptcy Law, Professor Jackson argued that the source of bankruptcy law is in the "common pool" problem and the prisoner's dilemma that it causes. ${ }^{7}$ In the case of insolvency, a company's assets are inadequate to cover payment of the company's debts in their entirety. The law grants the creditors the right to confiscate the assets to satisfy their unpaid claims; however, it is clear at the outset that the mutual reserves of company assets are insufficient to pay back the debts in full. Consequently, collection laws create an arbitrary method where "the early bird catches the worm"- - the creditors who reach the end of the collection process before the other creditors will succeed in getting their debts repaid in full, while the rest of them will be left empty-handed. This method creates a "race" of creditors towards the communal fund. This will have the effect of diminishing the amount of assets in the communal reserves and limiting the amount of debts

5. See, e.g., Richard V. Butler \& Scott M. Gilpatric, A Re-examination of the Purposes and Goals of Bankruptcy, 2 AM. BANKR. INST. L. REV. 269 (1994); Daniel T. Ostas, Postmodern Economic Analysis of Law: Extending the Pragmatic Visions of Richard A. Posner, 36 AM. BUS. L.J. 193 (1998); Reza Dibadj, Reconceiving the Firm, 26 CARDOZO L. REV. 1459 (2005).

6. See Block-Lieb, supra note 4; Susan Block-Lieb, Congress' Temptation to Defect: A Political and Economic Theory of Legislative Resolutions to Financial Common Pool Problems, 39 ARIZ. L. REV. 801 (1997); Susan Block-Lieb, The Logic and Limits of Contract Bankruptcy, 2001 U. ILL. L. REV. 503 (2001).

7. See Thomas H. Jackson, THE LogiC ANd Limits Of BANKRUPTCY LAW 1-19 (1986). 
that can be paid from the reserves. In other words; in the case of insolvency, the ordinary collection laws create a situation in which every single one of the creditors acts in a fashion that is detrimental to the common, collective interests of the aggregate of creditors. Bankruptcy law attempts to solve this dilemma by pooling all creditors together and subjecting them to collective proceedings.

Later in the book, Professor Jackson delves into an in-depth discussion on the contents of bankruptcy law, while trying to show that the existing set of laws does indeed match the idea of "the communal reserves." Furthermore, the author claims that the aims of bankruptcy law must be limited to that of solving the prisoner's dilemma, which is created as a result of the communal reserves phenomenon. ${ }^{8}$ Bankruptcy law's deviation from this goal would produce inefficient outcomes. ${ }^{9}$

Professor Jackson's theory greatly influenced the development of the later literature. In particular, authors that support social insights of bankruptcy law emphasized the limited spectrum that the idea of "the communal reserves" places on this field of law, while stressing that bankruptcy law provides answers for a wide variety of problems, not just the prisoner's dilemma problem. ${ }^{10}$ Gradually, even those supporting the economic analysis began to voice criticism towards Professor Jackson's theory. From these authors' point of view, the idea of communal reserves is problematic, since it appears to provide justification for the massive interference of the law in the relationship among the creditors themselves, and between them and the shareholders. ${ }^{11}$

The modern economic approach states that when individuals are given sufficient freedom, they will design their own contractual solutions to a possible insolvency ex ante. ${ }^{12}$ For instance, creditors who are interested in securing their payment in case of insolvency will make certain to obtain a security interest in the company's assets. The security interest mechanism is a bargained-for contractual term through which the creditors and the company bring to fruition their own desired solution. ${ }^{13}$ Likewise, if the parties fail in their attempts to design this possible solution at the outset, then they may, as a corrective measure, reach a private settlement agreement, which would again be outside the law's interference. When creditors are faced with a company that is undergoing hardships, they have incentives to try to rehabilitate the

8. See Robert E. Scott, Through Bankruptcy With the Creditor's Bargain Heuristic, 53 U. CHI. L. REV. 690 (1986) (book review).

9. See JACKSON, supra note 7.

10. See Warren, Bankruptcy Policy, supra note 3, at 790.

11. See Schwartz, Contract Theory, supra note 2, at 1831-34.

12. The most radical manifestation of this approach is found in Baird \& Rasmussen, The End of Bankruptcy, supra note 2, at 751-56.

13. See Thomas H. Jackson \& Anthony T. Kronman, Secured Financing and Priorities Among Creditors, 88 YALE L.J. 1143 (1979); Hideki Kanda \& Saul Levmore, Explaining Creditor Priorities, 80 VA. L. REV. 2103, 2112-14 (1994); Robert E. Scott, A Relational Theory of Secured Financing, 86 COLUM. L. REV. 901, 925-32 (1986). 
company, and voluntary efforts are preferable to legally-obligated efforts. ${ }^{14}$

Professor Alan Schwartz calls this solution "Contractual Bankruptcy Law." 15 If this concept is indeed correct, then the dominant approach in bankruptcy law should be to leave matters to private agreement. The law must respect, to the degree possible, the contracts which the parties have signed in anticipation of a possible insolvency. ${ }^{16}$

It is worth noting that this approach does not necessarily oppose the alternative of reorganization. However, it does oppose the element of coercion that is involved in every legal solution forced upon the parties by the court. In other words, a redistribution of the claims reached by agreement amongst the creditors is preferable to a redistribution mandated by the legal system. ${ }^{17}$

The End of Bankruptcy presents a contemporary variation of this approach that challenges the justification for reorganization proceedings. ${ }^{18}$ In this article, the authors Baird and Rasmussen claim that in the modern day, these proceedings are rarely used for the original purpose of "reviving failed businesses," and they actually serve the interests of the companies' owners, who wish to sell their businesses for more than they would have received had they sold the assets directly via the free market. ${ }^{19}$ Baird \& Rasmussen claim that most reorganization proceedings culminate in a sale of the "going concern" to a third party. ${ }^{20}$ The companies no longer undergo the regular reorganization process, where the going concern remains in the hands of the creditors and the original shareholders. Rather, the assets are sold to a willing buyer, and the original investors are rewarded financially for their holdings in the failed company. ${ }^{21}$ Additionally, in many cases, the bankruptcy court settles for enforcing the parties' pre-determined distribution of risks. ${ }^{22}$ In such cases, these proceedings lose their original character and become traditional proceedings for enforcing contracts. The element of coercion, which depicts the original bankruptcy proceedings, is gradually disappearing, in favor of proceedings in which the court implements the insolvency clauses that the parties agreed upon at the outset of their dealings. ${ }^{23}$

The authors base the explanation of this phenomenon on the inconsistent character of the market at the beginning of the third millennium. ${ }^{24}$ In the past,

14. See Schwartz, Contract Theory, supra note 2, at 1831.

15. Id.

16. Id. at $1842-44$.

17. Id. at 1849-51.

18. See Baird \& Rasmussen, supra note 2 , at $772-77$.

19. Id. at 777-78.

20. Id.

21. Id. at 788 .

22. Id. at 778-79. See also Barry E. Adler, A Theory of Corporate Insolvency, 72 N.Y.U. L. REV. $343,345,367-75$ (1997).

23. See Baird \& Rasmussen, supra note 2, at 786-88.

24. Id. at 755 . 
the value of traditional reorganization proceedings was based on the existence of special sources of value (known as "firm-specific assets") which were owned by the insolvent company, and which could not be transferred to a different entity without creating losses. ${ }^{25}$ Given that the company does indeed have special sources of value, reorganization of the company is the preferable solution-in liquidation proceedings, the liquidator must sell the company's assets, and therefore loses its special sources of value. ${ }^{26}$ When selling the company's assets part by part, it is impossible to realize the special sources of value, since these cannot be transferred to any other entity. Similarly, in the case of selling a company's business as a "going concern," the company will have to hand over the entirety of the company's assets to the buyer, who in turn, will not be able to enjoy the company's special sources of value. ${ }^{27}$ Only in the case of reorganization can the company continue to exploit its firm-specific sources of value, for the benefit of its creditors and shareholders. ${ }^{28}$

The traditional example of reorganization of bankrupt companies with firmspecific assets concerns the American railroad companies, which collapsed at the beginning of the previous century. These companies could not repay their outstanding debts, even though they had valuable assets, such as train cars, railroad tracks, and the like. Had the companies been forced to sell these assets, the value they would have received would have been substantially lower than the value of these assets within the framework of the railroad companies themselves. In this reality, the alternative of reorganization was the one most beneficial for the creditors and the shareholders of those companies. Thus, their creditors supported an "equity receivership," where the railroad companies had effectively been reorganized before the reorganization alternative was even incorporated into the Bankruptcy Code. ${ }^{29}$

The main claim of The End of Bankruptcy is that this economic reality has changed, and today, the economic reality that is analogous to that of the railroad companies exists in only a very small number of companies. ${ }^{30}$ In the vast majority of cases, the failed companies do not hold any special sources of value which cannot be realized when sold to a third party. ${ }^{31}$ Baird \&

25. For the notion of firm-specific assets as the basis for incorporation, see Ronald $\mathrm{H}$. Coase, The Nature of the Firm, 4 ECONOMICA 386 (Nov. 1937).

26. This claim was first made by Baird. See Douglas G. Baird, The Uneasy Case for Corporate Reorganizations, 15 J. LEGAL STUD. 127 (1986).

27. See Baird \& Rasmussen, supra note 2, at 756-58.

28. Coase's theory relies on the existence of transaction costs. As the efficiency of the market improves, these costs lessen. Id. at 778-79. Therefore, according to Baird \& Rasmussen, as the market becomes more efficient with lower transaction costs, there is no longer an economic justification for reorganization. Id.

29. See Douglas Baird \& Robert K. Rasmussen, Control Rights, Priority Rights, and the Conceptual Foundation of Corporate Reorganizations, 87 VA. L. REV. 921 (2001).

30. See Baird \& Rasmussen, supra note 2, at 758-60.

31. Id. at 773-77. 
Rasmussen point out a number of metamorphoses that the economy has undergone over the past few decades that have led to the gradual nullification of the companies' firm-specific assets. They claim that, especially in the current economic situation, the market is divided into "winning players" and "losing players," where the former succeed in taking control of the relevant market in its entirety, while the others gradually cease to exist. ${ }^{32}$ In a "winner takes all" reality, the losing players no longer hold any special sources of value which cannot be realized by selling the company's business to the winning players.

Therefore, the need and justification for the existence of complex judicial proceedings, in which the judge and the trustee seek a reorganization plan that will enable the continued existence of the company and that will satisfy a large number of the creditors, is gradually dissipating. In current reality, the legal system can make due with enforcing the insolvency terms that the parties agreed to at the outset of their contract.

The article, The End of Bankruptcy, aroused much criticism among those who specialize in economic analysis of the law. In particular, the critics claim that Baird \& Rasmussen develop their theoretical analysis on the basis of a factual description that is completely unrealistic. ${ }^{33}$ Empirical research shows that in most cases of insolvency, the legal system continues to enforce arrangements that coincide with the classic model of reorganization, where existing shareholders and creditors are the ones that receive possession of the company after rehabilitation. Selling businesses to a third party occurs only in the minority of cases. ${ }^{34}$ Likewise, empirical research emphasizes that Baird \& Rasmussen's analysis is based on the assumption that "the company's assets" establish the central justification for its existence. ${ }^{35}$ This assumption allows Baird \& Rasmussen to claim that the court and the parties prefer the selling of assets to a third party, if the sale occurs without losses. ${ }^{36}$ However, in reality, "the company's assets" are not its main resource. Instead, "relationships" between the company and its clients, between the company and its suppliers, between the company and its human resources, are what constitute its main source of value and what justify the existence of the legal entity. ${ }^{37}$ In every

32. Id. at $766-68$.

33. The criticism is directed at the claim that modern day sales of companies' assets to third parties result in losses. See generally Lynn M. LoPucki, The Nature of the Bankrupt Firm, A Response to Baird and Rasmussen's The End of Bankruptcy, 56 STAN. L. REV. 645 (2003). The criticism points to a consistent rise in bankruptcy and reorganization filings. Likewise, it shows that many substantial proceedings are customized to coincide with the traditional procedure, which Chapter 11 brought about. Finally, the criticism points to the companies' special sources of value today, and in doing so, singles out the special relationships that the company has cultivated with its clients, employees, suppliers, etc.

34. Id. at 660-65.

35. Id. at 652-57.

36. See Baird \& Rasmussen, supra note 2, at 786-88.

37. See LoPucki, supra note 33 , at 665-70. 
proceeding involving selling assets to a third party, whether the sale is for the entire "going concern" or for its individual parts, the relationships meaningful to the legal entity are lost. ${ }^{38}$ This is essentially the justification for preferring reorganization over liquidation, and this justification is what the critics of The End of Bankruptcy point to in explaining why most courts are not satisfied with simply enforcing the pre-existing contracts between the parties.

Until now, I have focused on the criticisms voiced by those who specialize in economic analysis of the law. However, the social approaches regarding bankruptcy law take issue with the exclusive focus on the economic aspect of the collective proceedings. Professor Korobkin's opinion is that bankruptcy law aims to provide answers with respect to all aspects of the financial distress phenomenon, including its emotional, political-social, moral, and indeed, its economic aspects. ${ }^{39}$ Insolvency exacerbates the conflicts of interest between the parties involved. Therefore, the law attempts to provide a forum where interests and values can be expressed, without having to choose one of them exclusively. ${ }^{40}$ As Professor Warren emphasizes, in contrast to the advocates of the economic approach, whose sole aim is to enlarge the value paid to the creditors in the event of insolvency, the advocates of the social approaches stress the multitude of aims and values that form the basis of bankruptcy law. ${ }^{41}$

Warren claims that the central aim of bankruptcy law is the distributive consideration: given that the losses of the failed business must be distributed, the primary role of the law is to determine how to distribute those losses. ${ }^{42}$ She claims that there are different kinds of values that must be taken into account when deciding the distribution scheme, and none of the values outweighs any other. $^{43}$

The criticism of the economic approach emphasizes that it is wrong to

\section{Id. at $651-52$.}

39. See Korobkin, Rehabilitating Values: A Jurisprudence of Bankruptcy, supra note 3, at 718-22. For a later presentation of this approach, in the broader context of the place of theoretical analysis in bankruptcy literature, see Korobkin, The Role of Normative Theory in Bankruptcy Debates, supra note 3 , at 75-80.

40. Recently, Korobkin has broadened the approach that views bankruptcy proceedings as a "stage" for expressing the different conflicts of interest, which in light of the insolvency, cannot be bridged. In this analysis, Korobkin draws a comparison between the legal system and the performing arts, and points out the importance of the judicial process as one which gives rise to the expression of different basic insights. In this sense, bankruptcy law is an essential mechanism for dealing with loss and failure. See Korobkin, Bankruptcy Law, Ritual and Performance, supra note 3, at 2124-31.

41. See generally Warren, Bankruptcy Policy, supra note 3. For Baird's response to Warren, see Douglas Baird, Loss Distribution, Forum Shopping and Bankruptcy: A Reply to Warren, 54 U. CHI. L. REV. 815 (1987). In a later work, Warren presents an empirical analysis which portrays the complexity of insolvency procedures and the impossibility of reaching a clear, one-dimensional conclusion as to the aims of the proceedings. See Warren \& Westbrook, supra note 3. Elsewhere, the author discusses her approach in the context of the reform that has recently taken place in Article Nine of the U.C.C. See Elizabeth Warren, Making Policy with Imperfect Information: The Article 9 Full Priority Debate, 82 CORNELL L. REV. 1373 (1997).

42 See Warren, Bankruptcy Policy, supra note 3, at 789-93.

43. Id. at $790-93$. 
expect that contractual solutions will reach better and more efficient results than the arrangements which are forced upon the parties by law. ${ }^{44}$ In this regard, the literature stresses three central considerations:

1. Confusion between form and content: From the point of view of the parties to the dispute, the main question is: what is the content of the applied arrangement, as opposed to its source (whether contract or law)?

2. Effect on third parties: In the case of insolvency, every agreement between the debtor and one of his creditors affects the other creditors. The advocates of the economic approach, who rely on settlement and contracts, disregard the effect of such contracts on the other creditors who were not parties to the contracts.

3. Costs of the agreement: The assumption that it is cheaper to agree upon a settlement and a solution rather than to utilize the legal mechanism is wrong, since the contractual arrangement and its execution involve substantial costs that are higher than the cost of implementing the law. ${ }^{45}$

\section{B. Procedural Aims vs. Substantive Aims}

An additional conflict that arises from the different approaches revolves around the issue of classifying these laws. According to one of the approaches, bankruptcy laws supply, first and foremost, a mechanism for collecting debts, and as such, they belong in the field of procedural law. ${ }^{46}$ According to the other view, bankruptcy laws seek to supply effective mechanisms for restoring the company's economic resources to productive business activity. ${ }^{47}$ Among other things, reorganization law attempts to give a failed business another opportunity. In order to achieve such rehabilitative goals, ${ }^{48}$ bankruptcy laws must completely reorganize all of the company's legal liabilities. In other words, bankruptcy laws are part of the field of substantive law, which define and formulate individuals' rights, and do not solely provide the mechanism used to enforce these rights.

This dilemma between procedural and substantive categorization directly affects the contents of bankruptcy law. Scholars who uphold the procedural classification emphasize that bankruptcy laws must avoid "redistributing" the layout of the essential rights. Like any other procedural mechanism, bankruptcy

44. See Block-Lieb, The Logic and Limits of Contract Bankruptcy, supra note 6, at 527-29.

45. Id. at 511-18.

46. For a radical expression of this approach, see Mooney, supra note 1.

47. For an expression of this approach, see Korobkin, Rehabilitating Values: A Jurisprudence of Bankruptcy, supra note 3.

48. The judicial decisions recurrently emphasize the rehabilitation goals of bankruptcy proceedings. See Miller v. United States, 363 F.3d 999, 1004-05 (9th Cir. 2004); In re Dicey, 312 B.R. 356 (Bankr. D.N.H. 2004); In re Dawley, 312 B.R. 765, 781-782 (Bankr. E.D. Pa. 2004); Mt. McKinley Ins. Co. v. Corning Inc., 2003 U.S. Dist. LEXIS 4295, at *28-29 (S.D.N.Y. Mar. 20, 2003), reconsideration denied, 2003 U.S. Dist. LEXIS 9977 (June 16, 2003), vacated and remanded, 399 F.3d 436 (2d Cir. 2005). 
laws must remain loyal to the rights that existed before the event of insolvency, and must limit themselves to enforcing these existing rights. ${ }^{49}$ In contrast, scholars who advocate the substantive classification emphasize the necessity of reorganizing the rights to the company's assets, in order to enable the realization of the substantive goals of the procedure. In particular, in order to make reorganization of the company possible, all parties must understand and accept that at least some of their pre-bankruptcy rights cannot immediately be enforced. $^{50}$

It is interesting to note that in the past, this dichotomy with respect to the classification of bankruptcy law was closely bound with the conflict between the economic and social approaches. The supporters of the economic view identified with the procedural classification, while the supporters of the social view gravitated towards the substantive classification of these laws. Therefore, it was the advocates of the economic analysis who so vehemently opposed the reorganization arrangement of the company, since every reorganization plan involves a certain degree of violation of prior entitlements, as well as a violation of the priority rules that govern the distribution of the company's assets in liquidation proceedings. ${ }^{51}$

For example, an essential pre-condition for the company to return to its efficient activity is the minimization of its outstanding debt; however, the lessening of the burden of outstanding debt is only possible after a process in which some of the creditors waive their debts in exchange for other rights in the rehabilitated company. In other words, reorganization plans involve the restructuring of the company's capital structure, such that some of the creditors will have no choice but to exchange their loans or bonds for stock or options in the reorganized company. This exchange alters the arrangement of the original, substantive rights that the creditors had prior to the event of insolvency. ${ }^{52}$ In a similar manner, the reorganization proceeding affects the distribution of claims between the different creditors in the company, and between them and the shareholders. Even when the law requires that the reorganization plan satisfy the absolute priority rule, reality shows that the reorganization proceeding involves a certain amount of "cram down" of senior debts, to the benefit of the

49. This is Jackson's view. See JACKSON, supra note 7.

50. The most radical expression of stalling the enforcement of original rights is found in denying the secured creditors their right to immediately enforce their security interests. For the effect of reorganization on the rights of secured creditors to immediate foreclosure, see infra Part IV.B.

51. See Lucian A. Bebchuk, A New Approach to Corporate Reorganizations, 101 HARV. L. REV. 775, 777-81 (1988); Lucian A. Bebchuk \& Howard F. Chang, Bargaining and the Division of Value in Corporate Reorganization, 8 J.L. ECON. \& ORG. 253 (1992).

52. This is the feasibility requirement. See 11 U.S.C. $\$ 1129$ (a)(11) (1994). For application of the feasibility requirement, see In re Wood, 1991 U.S. Dist. LEXIS 20083 (Bankr. W.D. Va. Nov. 11, 1991); In re Cheatham, 91 B.R. 377 (Bankr. E.D.N.C. 1988); In re Stapleton, 55 B.R. 716 (Bankr. S.D. Ga. 1985); Danny Thomas Props. II Ltd. P'ship v. Beal Bank, 241 F.3d 959 (8th Cir. 2001); Kane v. Johns-Manville Corp., 843 F.2d 636 (2d Cir. 1988); In re Pikes Peak Water Co., 779 F.2d 1456 (10th Cir. 1985); In re Sea Garden Motel \& Apts., 195 B.R. 294 (Bankr. D.N.J. 1996). 
junior creditors and the shareholders. ${ }^{53}$

Today, the advocates of the economic approach distance themselves from the procedural classification of bankruptcy law. In particular, Baird \& Rasmussen ${ }^{54}$ show how the absolute priority rule, which dominates the priority orders in liquidation, is expected to produce inefficient results in the case of reorganization. ${ }^{55}$ Since the managers of the company before the reorganization procedures are the shareholders' representatives or the shareholders themselves, the shareholders must receive a promise to get a "piece" in the rehabilitated company. Allocating a piece of the new company to the old shareholders is essential, in order to ensure that they will be motivated to act towards effectively rehabilitating the company. Furthermore, a necessary condition for reorganization is injecting new credit into a failed business. Baird \& Rasmussen show that the shareholders of the company are the best candidates for investing more money in a failed business. ${ }^{56}$ In contrast to other investors, who fear a reappearance of the past failures of the company, the existing shareholders are aware of the company's potential value and therefore willing to provide the financial sources needed to rehabilitate the company. In order to motivate the shareholders to continue investing in the company, they must share in the increase in the company's value generated by the reorganization. In essence, there must be a deviation from the absolute priority that places creditors over shareholders.

\section{Micro-Economic Aims vs. Macro-Economic Aims}

Until now, I have assumed that an event of insolvency is a specific event for the individual company, which affects only the creditors and shareholders of that company. In the past, events of insolvency were perceived as merely micro-economic phenomena, and the bankruptcy laws were perceived as part of the private law. However, over the passage of time, reality overturned this underlying assumption. The economic crisis of the late 1920 s showed that at times, a company can reach the point of insolvency due to factors affecting the

53. See Bebchuk \& Chang, supra note 51 and the references therein.

54. See Baird \& Rasmussen, supra note 29.

55. It is interesting to note that these developments reflect the intellectual development of Professor Baird himself. At the beginning, Baird joined Jackson and developed the argument that there is no economic justification to reorganize companies since it is possible to realize the going concern value by selling the business to a third party in liquidation. In light of the redistributive effect involved in reorganization, Baird claimed that this proceeding must be avoided. See Baird, supra note 26. At a later point in time, Baird joined Rasmussen in an article that advocated reorganizations and the avoidance of the absolute priority rule. See Baird \& Rasmussen, supra note 29 . Finally, the two embarked on an additional article that ostensibly seems to contradict the previous one, and argued that there is no longer any justification for the existing bankruptcy law. In this article, the authors emphasize that the railroads can no longer be used as the guiding example, since the circumstances of that case are substantially different from the circumstances that revolve around most of the cases of insolvency today. See Baird \& Rasmussen, supra note 2.

56. See Baird \& Rasmussen, supra note 29 , at $954-58$. 
entire market, leaving the individual company with no control over the situation.

From the macro-economic point of view, there should be an attempt to reorganize failed businesses. According to the modern macro-economic approaches, government and legal systems should interfere in times of depression to prevent an economic crisis which may "snowball" and cause the downfall of many other firms. ${ }^{57}$

The reorganization of failed companies is desirable because it contributes to limiting the crisis, while liquidation is undesirable because it encourages the "snowball" effect. ${ }^{58}$ When a company is liquidated, its assets are put on a quasi-"public auction," and its employees fall outside of the workforce. As long as the insolvency phenomenon is specific, these occurrences have no macroeconomic effect. However, when the market is in a crisis, many companies reach insolvency and liquidation. Great numbers of assets are put up for sale and many employees are discharged from the workforce. The liquidation proceedings intensify the economic crisis-selling the assets contributes to the drop in the market prices of the economic resources, and the discharge of the employees from the workforce contributes to further minimization of aggregate demand.

In contrast, reorganization contributes to moderating an economic crisisthe postponement in selling the companies' assets and in discharging the employees supplies the time necessary to recover from the crisis. Likewise, in the event that the reorganization attempt succeeds and the company returns to productive business activity, the selling of the companies' assets is avoided and the employees remain in the workforce. Finally, when dealing with relatively large companies which have relatively large liabilities, settlements made with banks to delay due dates and to perfect terms of credit are multi-partied arrangements, in which not only the failing company's direct creditors take part, but also the creditors of the banks themselves. Thus, reorganization allows avoidance of the "snowballing" effect of crisis-induced insolvency. ${ }^{59}$

57. See, e.g., Carl A. Auerbach, Is Government the Problem or the Solution?, 33 SAN DIEGo L. REV. 495 (1996) and the references therein.

58. This argument was first introduced by Harvey Y. Miller \& Shai Y. Waisman, Does Chapter 11 Reorganization Remain a Viable Option for Distressed Businesses for the Twenty-First Century?, 78 AM. BANKR. L.J. 153, 156-78 (2004). One may find some variations of this argument in Chapman, supra note 3; see also Mark Kelman, Could Lawyers Stop Recessions? Speculations on Law and Macroeconomics, 45 STAN. L. REV. 1215 (1993); Robert B. Seidman et al., Big Bang and Decision Making: What Went Wrong, 13 B.U. INT'L L.J. 435 (1995).

59. See, e.g., Margaret Howard, Bankruptcy Empiricism: Lighthouse Still No Good, 17 BANKR. DeV. J. 425, 436 (2001) (reviewing Teresa A. Sullivan et al., The Fragile Middle Class: AMERICANS IN DEBT (2000)). 


\section{INEFFICIENT ENTITLEMENTS AND LEGAL COERCION}

\section{A. General}

The above discussion of conflicting views of bankruptcy law demonstrates how all of these views share the premise that efficiency considerations support the preservation and the enforcement of prior entitlements. Jackson limits the interventionist effect of bankruptcy law to the resolution of the "common pool" problem. ${ }^{60}$ Schwartz's "Contractual Bankruptcy Law" emphasizes the efficiency value of enforcing pre-existing contracts dealing with the allocation of insolvency risks. ${ }^{61}$ Baird \& Rasmussen highlight the decline of firm-specific assets as a justification for avoiding the redistributive effect of reorganization. ${ }^{62}$ While the social theories call for alternative solutions, they all rely on policy considerations that are not related to efficiency. Warren emphasizes the rehabilitative and distributive values of bankruptcy law. ${ }^{63}$ Korobkin emphasizes the need to provide the parties who suffer the losses of insolvency the right to express their frustration in order to reach collective solutions. ${ }^{64}$ Accordingly, the debate remains loyal to the traditional conflict between efficiency-oriented laws and legal arrangements that aim at optimizing distributive justice.

This accepted starting point relies on two major normative considerations. First, the enforcement of contractual arrangements is necessary to enable efficient planning of credit transactions by solvent companies. ${ }^{65}$ When creditors anticipate that a company's insolvency will leave them unpaid, they can choose to increase their interest rates or subject the company to more restrictive covenants. Furthermore, any uncertainty involved in the expected outcome of bankruptcy proceedings is reflected in higher risks and higher costs of finance. Thus, ex post interference with prior entitlements increases the cost of capital ex ante, to the detriment of solvent companies and their shareholders. ${ }^{66}$ To avoid this effect, bankruptcy courts should refrain from interfering with existing entitlements, and settle for enforcing the pre-planned allocation of insolvency risks. ${ }^{67}$

Second, when parties cannot expect the court to alter the existing entitlements in their favor, they will be encouraged to structure an efficient process of renegotiation. Inefficient contracts and liabilities would be altered to reflect the parties' better understanding of their relevant needs. ${ }^{68}$

60. See JACKSON, supra note 7.

61. See Schwartz, Contract Theory, supra note 2.

62. See Baird \& Rasmussen, supra note 2.

63. See Warren, Bankruptcy Policy, supra note 3.

64. See Korobkin, Bankruptcy Law, Ritual and Performance, supra note 3.

65. See Schwartz, Contract Theory, supra note 2, at 1842-51.

66. See supra note 13 and the references therein.

67. Id.

68. See Jagdeep S. Bhandari \& Lawrence A. Weiss, The Untenable Case for Chapter 11: A Review 
Nevertheless, any acquaintance with the practical reality of insolvency cases teaches that while the above policy considerations are powerful, they cannot fully exhaust the relevant efficiency-based considerations. In many cases, corporations reach financial distress because they had engaged in contracts and liabilities that bound them into conducting inefficient activities. These corporations file for reorganization after they fail to renegotiate their contracts with their creditors, namely their lenders, employees, vendors, and customers. In real world cases, companies do not go bankrupt at the point of insolvency, but rather at the point when they cannot acquire new financial resources to meet their current liabilities. ${ }^{69}$ In turn, their failure to obtain new capital is the result of the existing inefficient entitlements, since every potential new investor expects that after the company fulfills its current liabilities, no resources would remain to cover his or her new debt, or to provide him or her with positive returns on equity investment. ${ }^{70}$ Under these conditions, bankruptcy law can never fully enforce the existing entitlements, and the above policy considerations cannot be fully upheld. Furthermore, even if some of the company's creditors have contracted ex ante for the allocation of insolvency risks, the full enforcement of these contracts in bankruptcy proceedings will usually decrease, rather than increase, the aggregate value to all other creditors. ${ }^{71}$ In other words, some of the agreements between the company and its creditors for the allocation of insolvency risks may involve inefficient entitlements. Then, in order to reconvert the company's assets into efficient business activity, some contractual provisions must be avoided.

The more challenging task is to translate this unfortunate reality into a theoretical framework of bankruptcy law. To do so, one must inquire into the sources of inefficient entitlements and into the reasons that the renegotiation process fails.

\section{B. The Meaning and Sources of Inefficient Entitlements}

Prior entitlements are inefficient when they drive the company into suboptimal actions. Thus, inefficient entitlements are characterized by two elements: first, the company partakes in a sub-optimal activity subsequent to the entitlement; and second, there exists a causal relationship between the entitlement and the future sub-optimal activity. (Figure No. 1 presents this

of the Evidence, 67 AM. BANKR. L.J. 131, 133 n.8 (1993) and the references therein.

69. See Douglas G. Baird, Bankruptcy's Uncontested Axioms, 108 YALE L.J. 573, 580-83 (1998).

70. In many cases, bankruptcy proceedings are essential for obtaining the necessary credit for maintaining the business activity. See infra Part IV.B.

71. For example, secured creditors contract $e x$ ante for immediate foreclosure upon the commencement of bankruptcy proceedings. Nevertheless, an immediate sale of assets may impede the survival of the going concern. If the going concern's value is higher than the asset value, then the full enforcement of the rights of secured creditors would decrease the aggregate value of the bankrupt estate. Accordingly, 11 U.S.C. $\S 362(2000)$ subordinates the secured creditors to the automatic stay. 
chain of events on the time-axis.)

\section{Figure No. 1: The Chain of Events on the Time-Axis}

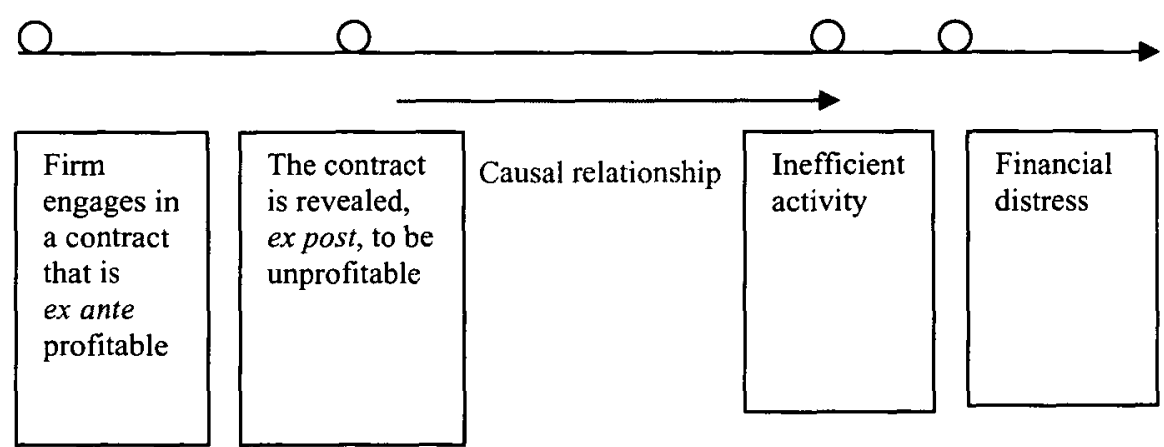

How can a contract at some earlier point in time, $\mathrm{t}_{0}$, yield a sub-optimal activity at some later point in time, $t_{n}$ ? The answer to this question stems from the gap between the expected profitability of the contract, ex ante, and its actual profitability, ex post, and from the impact of the unprofitable contract on the future activities of the company. When the company enters into the initial contract, it expects this contract to be profitable. The company measures the expected profitability of the contract by its expected returns, that is, it relies on a probability analysis of all possible factors. For example, when the company employs a new employee, it expects that his or her contribution to the company's value will exceed the costs of employment. When the expected contribution is unknown, the company estimates the contract's value by using the expectation function. The company estimates the probability distribution over all possible scenarios, and then sums up the products of the assigned probability values and the expected cash flows under each of the identified scenarios.

Only one of these expected scenarios will manifest itself to be the actual scenario. The real contribution of the contract will usually differ from its expected value. ${ }^{72}$ If the real contribution of the contract is substantially lower than the expected value, then the contract may prove to be unprofitable. For

72. The following simplistic example clarifies this point: assume that a company employs a sales agent to market new products. The employment contract is made under uncertainty, both as to the actual demand for the new product, and as to the capability of the sales agent. Assume that the expected value is calculated according to the following possible scenarios: 1. Under the first scenario, both the demand for the product and the agent are favorable. Then, the firm would earn from this agent's sales a value of ten; 2. Under the second scenario, either the agent or the demand is less favorable, and therefore, the firm would earn only five; 3 . Finally, under the last scenario, the actual demand is much lower than expected, and therefore, the firm's value from the sales is reduced to zero. If all scenarios are equally probable, then, the expected value is five. The firm would be willing to pay the agent a salary of two. Now, if the third scenario is the one that materializes, then, the contract is revealed to be unprofitable. 
example, if the contribution of the employee described in footnote 72 is significantly lower than what the company had expected, then the employment of this particular employee is unprofitable. ${ }^{73}$ A contract may also be revealed to be unprofitable due to macro-economic events. For example, in the context of employment, the boom of the hi-tech industry towards the end of the last century led to a dramatic increase in the average salary of software developers. Then, following the collapse of this industry in 2002, the average salary dropped dramatically. As a result, companies that hired developers in 1999 and in 2000 , found themselves bound by sub-optimal contracts in $2002 .^{74}$

It has generally been thought that unprofitable contracts only involve distributive effects. ${ }^{75}$ For example, in the context of employment, it appears that the negative returns for the company are counteracted by positive returns for the employees, such that aggregate efficiency remains unchanged. Deeper reflection reveals, however, that unprofitable contracts may drive the company into inefficient activities. For example, the excessive employment costs may force the company to reduce its investment in new technologies or in new products. Because this company continually competes against other similar companies over potential investors, it must retain a competitive level of net returns. Thus, if the company incurs excessive employment costs, it must, ceteris paribus, reduce its other costs. ${ }^{76}$ In the long run, the sub-optimal investment may result in sub-optimal returns.

In sum, unprofitable contracts lead to sub-optimal activities because they influence the subsequent decisions of the company and because they may distort the incentives of the company's incumbents to maximize aggregate returns. ${ }^{77}$ The following examples demonstrate concrete cases of inefficient entitlements:

a. Unreasonable burden of debt: At times the company is led, either by choice or otherwise, into a situation in which its burden of debt is incredibly high. The high leverage ratio is likely to lead to inefficient activity, since the

73. Indeed, the parties may contract against the pessimistic events, but as will become apparent in the following discussion, any form of defense measure against the risks of suboptimal contracts is inherently incomplete and is not without costs.

74. While these firms could theoretically dismiss these employees, the termination of employment contracts involves tremendous costs.

75. See, e.g., Juliet P. Kostritsky, Illegal Contracts and Efficient Deterrence: $A$ Study in Modern Contract Theory, 74 IOWA L. REV. $115,118 \mathrm{n} .8$ (1988), and the references therein.

76. Otherwise, the company will not be able to compete with other players over new investments.

77. Indeed, the law does not support the possibility of adapting a contract to new events and realities. Contract law states that a mistake as to the profitability of a contract will not justify the nullification of the contract. See La. Power \& Light Co. v. Allegheny Ludlum Indus., 517 F. Supp. 1319, 1327 (E.D. La. 1981); Wooldridge v. Exxon Corp., 473 A.2d 1254, 1257 (Conn. Super. Ct. 1984); L-J, Inc. v. S.C. State Highway Dep't, 242 S.E. 2d 656, 662-63 (S.C. 1978); Hill v. A.O. Smith Corp., 801 F.2d 217, 222 (6th Cir. 1986). All of these cases rely on the doctrine requiring that the mistake refer to past or present facts that already exist at the time the contract is made. A mistake cannot refer to erroneous predictions of the parties concerning future facts. 
company is acting under immediate pressures to pay its outstanding debt.

b. Substantial alterations in interest rates: Interest rates change from time to time, and this variance affects the advantageousness of the company's existing loans. In the event that the market interest rate drops substantially below the interest rates on the company's existing debt, the cost of the company's credit becomes excessively expensive. The company is forced to pay higher interest rates than it could have attained through a current credit transaction. High credit costs are likely to lessen the company's competitive power in the market. The company will be forced to sell its products at higher prices than its competitors, or be satisfied with smaller profits, or both. In any event, reducing the profitability is expected to lessen the shareholders' incentives to continue investing in the company.

c. Gradual growth over time, beyond that which is expected, in the total value of required investments: Despite management's best efforts to accurately estimate the costs of development, production, and operation at the outset, its foresight is far from perfect. In many cases, these costs will be higher than expected. Then, the company will be bound to enlarge its fixed liabilities beyond the budgeted amount. Higher costs are likely to cause inefficient utilization of the company's assets-management is likely to be swayed by its interest to minimize those costs, even at the price of deviating from its output goals. In other cases, the heightened costs could lead to the need to raise additional capital, under less favorable conditions than those which existed at the original planning stage.

d. Development of inefficient control: The holding of shares determines corporate control. The guiding principle places the control in the hands of the shareholder who holds more than $50 \%$ of the company's shares. In many cases, this principle can lead the company into inefficient control. For example, the controlling group may be comprised of a number of shareholders who suffer from major disagreements and coordination problems. Another example is the struggle for power among the founders of a start-up company and its investors, which is likely to lead to inefficient decisions. In general, collective action problems may thwart the efficient management of assets.

e. Substantial alterations in the supply and demand for the business's workers: The company determines employment conditions with each employee according to the conditions of the relevant job market at the beginning of the employment. As a result, substantial changes in the relevant job market are expected to affect profitability and efficiency. For example, should the customary employment conditions of the market deteriorate after the employment of some of the workers, and assuming that the company is bound to the original salary agreements, then the company will be in a position in which the costs of its workforce are substantially higher than the same costs of competitor companies that hire similar employees at later dates. Naturally, the 
company will seek to terminate its current employment contracts, but it will not always succeed in doing so. Uniquely skilled workers, who by definition would be hard to replace, will tend to insist on the continuance of their original employment terms. Further difficulties in altering the employment contracts will ensue if the workers are part of a union.

f. Substantial decrease in the demand for the company's products: Longterm changes may decrease the demand for the company's products. For instance, novel technologies obviate the demand for old technologies. In addition, changes in the course of business activity eliminate the need for certain products and services, and create demand for new products and services. The passing of generations and changes in consumption habits have similar effects.

In some cases, the company will succeed in adapting its production channels to the dynamic market, and will thus succeed in retaining efficient activity. In other cases, the company will not be so fortunate. In these cases, efficiency dictates the release of the assets from the existing arrangement of liabilities. This can be done by selling the assets piecemeal so that every buyer makes varying use of them, or by selling the assets as a "going concern" to a buyer who will be able to make the necessary adjustments in the company's products. Notwithstanding efficiency considerations, incumbents may object to such sales for personal reasons, and in doing so, would maintain the misallocation of resources in the company's hands.

g. Macro-economic changes in the economy: Finally, macro-economic changes are expected to affect the advantageousness of the existing activity in the company. The salient example of this in the Israeli economy is that of the tourist industry, which was severely harmed as a result of the outbreak of the second Intifada, and has not yet recovered. Investors would most likely never have invested in this field had they been able to foresee these developments. ${ }^{78}$

On a higher level of abstraction, inefficient entitlements may emerge from one or more of the following three potential sources:

a. Unprofitable Contracts (hereinafter, the first source of inefficiency): The major source of financial distress concerns the sub-optimal terms of the company's contracts. An excessively high leverage ratio, sub-optimal employment contracts, or sub-optimal interest rates are examples of this possibility. Under these conditions, the sub-optimal contracts deter new investment because potential investors expect that the company would lose too much value from zeroing out its current liabilities.

78. Note that the latter two paragraphs assume a wider definition of the term "entitlement." They assume that entitlements refer to a wide spectrum of commitments towards third parties. For example, if the firm engages in various investments, such as the construction of new hotels, it inherently engages in various contracts such as contracts with contractors. As a result, the firm provides these third parties various entitlements. 
b. Inefficient control (hereinafter, the second source of inefficiency): The second possibility is that problems in the company's management or its control are preventing it from optimal activity.

c. The lack of potential cash-flow (hereinafter, the third source of inefficiency): Finally, it is also possible that changes in the times and customs will lead to a decrease in the demand for the company's products, or that the price of manufacturing these items will rise dramatically. These possibilities would serve to diminish the company's expected stream of income.

Fixed liabilities, by their nature, endanger the efficient activity of the company, since they limit the company's ability to adjust to the changing marketplace. The parties set the terms of the fixed liabilities at the time they enter into the contract; however, a reality different from what the parties originally expected may be revealed when actually executing the commitment. The gap between the parties' expectations at the time of the creation of the fixed liabilities and the business reality that is exposed at the point of their execution, may render the existing arrangement of liabilities unprofitable. The lack of profitability may lead the company to knee-jerk decisions and actions, which may reduce the long-run aggregate value of the company.

Therefore, if it were possible, companies would completely avoid entering into fixed liabilities, and would instead offer all of its parties some share in its aggregate proceeds. In actuality, avoiding fixed liabilities is impossible, and is not necessarily the most efficient choice for the company. Firstly, there are contracting parties who would not agree to residual consideration. Such parties include banks and the company's employees, ${ }^{79}$ suppliers, ${ }^{80}$ and consumers. ${ }^{81}$ Even if these investors would agree to stipulations that would make the company's liabilities towards them more flexible, these stipulations would remain marginal without changing the comprehensive character of the contract. The company is therefore forced to bind itself in a fixed commitment upfront, whether it likes it or not. Secondly, a residual claim against the company's assets is usually related to the investor's power to influence decision-making in the company. ${ }^{82}$ Thus, for example, it is the shareholders who appoint the company's directors and managers, and who control the company's decisionmaking. Other investors as well will seek to condition the requested flexibility of their contract on their power to affect the decision-making in the company. Broadening the number of residual claims entails broadening the number of

79. The vast majority of the employees would like to receive a fixed salary that is independent of the business's returns.

80. Suppliers would usually require fixed prices that are independent of the company's returns.

81. Consumers would expect the company to demand some fixed price for its product. While the prices may change over time, they by no means depend on the corporation's returns.

82. For the connection between residual claims and corporate control, see HENRY HANSMANN, THE OWNERSHIP OF ENTERPRISE (1996); Henry Hansmann \& Reinier Kraakman, The Essential Role of Organizational Law, 110 YALE L.J. 387 (2000). 
individuals who take part in the decision-making process of the company. This broadening is likely to lead the company into stagnation and an inability to operate, for the same collective action reasons previously discussed.

In other words, every form of contracting with the company may lead to an arrangement of claims that will thwart the efficient operation of the company's assets. Fixed claims threaten to limit the company's flexibility and ability to adjust itself to the dynamic marketplace; residual claims, like stock, threaten to create an inefficient arrangement of decision-making in the company. Throughout its course of activity, the company attempts to strike a balance between its possible types of inefficiency, and in doing so, varies the kinds of claims made against it. The company balances between generating capital through the issuance of loans and generating capital through the issuance of shares. Likewise, the company can include stipulations in its contracts with the different claimants, thus making the contracts more flexible to change in a dynamic world. However, this attempt to balance between the different types of inefficiency does not always succeed in leading to the efficient management of the company's assets. Whether due to a lack of choice, a case of misjudgment, or as a result of unforeseeable events, the company may be led into a situation in which it will be bound by inefficient contracts. In such a case, releasing the assets from the existing arrangement of liabilities is vital in order to shift the assets back to productive activity.

\section{The Failure of the Renegotiation Process}

When an inefficient arrangement of liabilities against the company is formed, the problem can be solved in one of two ways: first, the parties can draft new contracts that would serve to nullify the original ones, thus effectuating a private solution that requires some commercial flexibility by the parties; and second, the company can undergo a court-ordered reorganization or liquidation proceeding. ${ }^{83}$

The discussion in the following paragraphs shows how private solutions to inefficiency are preferable to court-mandated solutions. Therefore, the discussion will show that reorganization or liquidation should become relevant only upon the parties' failure to solve the inefficiency independently through a redrafting of their contracts. ${ }^{84}$

There are several reasons why the parties cannot always reach an efficient private solution. In some cases, coordination and cooperation difficulties arise.

83. See Schwartz, Contract Theory, supra note 2, at 1849-51.

84. Under particular circumstances, the debtor's effort to renegotiate his liabilities is considered to be a pre-requisite for establishing good faith. See In re East, 270 B.R. 485, 495 (Bankr. E.D. Cal. 2001) (discussing the duty of former students to make an effort to renegotiate their student loans prior to filing for bankruptcy); see also In re Mort, 272 B.R. 181, 185-86 (Bankr. W.D. Va. 2002); In re Conner, 89 B.R. 744, 747 (Bankr. N.D. Ill. 1988); In re Stern, 288 B.R. 36, 43 (Bankr. N.D.N.Y. 2002). 
All of the claimants in the company expect to enjoy an improvement in the existing arrangement of liabilities against the company; however, every investor prefers, of course, that the other investors bear the costs of this expectation. Thus, for example, a lender to the company will prefer to continue to receive the interest that was agreed upon in the loan contract, even when the contractual rate is higher than that of the market, by way of expecting that the company's other creditors will agree to minimize their claims on the company. As another example, when the company is in need of new sources of funding, every shareholder will prefer that the other shareholders will continue to invest further resources in the company. Finally, if new employment contracts are necessary, every worker will prefer that the company subject its other workers to altered employment terms, while maintaining the original terms for his own employment.

When the company's assets are led into inefficient activity, the conflicts of interest between the creditors and the shareholders intensify. Inefficiency causes losses, and these losses are passed on to either the shareholders or the creditors. The party that is harmed from the inefficiency will ask to alter the existing arrangement of liabilities, while the unharmed party will insist on retaining the status quo. Indeed, it will usually be the shareholders who will ask to change the existing arrangement, since they have the incentive to see the assets restored to efficient use. Thus, for example, when the inefficiency is caused by excessively high salaries, the controlling shareholders will try to hold an additional round of bargaining in an attempt to lessen the value of the comprehensive liabilities towards the workers. Naturally, the workers will try to reject the controlling shareholders' objective. Their success in doing so will turn on the uniqueness of their skills and on the strength of their organization. To the extent that the company's workers succeed in preventing alterations to their employment contracts, they are likely to drag the company's assets into inefficient activity. This holds true because the workers are motivated by their own interests, and not by an interest to achieve aggregate efficiency.

In exceptional cases, it will be the company's creditors who will ask to change the existing arrangement of liabilities, and it will be the shareholders who will play spoiler. This situation may occur when the company takes out an additional loan from a later creditor, thus diluting the rights of the earlier creditors. ${ }^{85}$ When the comprehensive burden of loans creates substantial

85. For the problem of creditors' dilution, see Clifford W. Smith, Jr. \& Jerold B. Warner, On Financial Contracting: An Analysis of Bond Covenants, 7 J. FIN. ECON. 117 (1979); see also George G. Triantis \& Ronald J. Daniels, The Role of Debt in Interactive Corporate Governance, 83 CAL. L. REV. 1073, 1109 (1995); Randal C. Picker, Security Interests, Misbehavior, and Common Pools, 59 U. CHI. L. REV. 645, 652 (1992); Scott, supra note 13, at 920; Alan Schwartz, Priority Contracts and Priority in Bankruptcy, 82 CORNELL L. REV. 1396, 1396-99 (1997); Houman B. Shadab, Interpreting Indentures: How Disequilibrium Economics and Financial Asset Specifically Support Narrow Interpretation, 75 S. CAL. L. REV. 763, 764-65 (2002). 
dangers of insolvency, the earlier creditors will ask that the company direct its efforts to minimizing the credit burden. In these cases, the shareholders may refuse to cooperate with the earlier creditors if the benefit from the later financing outweighs its inefficiency.

\section{Financial Distress}

Inefficient liabilities threaten to lead the company to financial distress. First, they reduce the company's returns, and thereby, increase the company's needs for new funding; and second, they reduce the incentives of new investors to provide the company with new financial resources. As a result, after a while, the inefficient liabilities may lead to a situation where the company lacks the necessary finance to meet its current debts.

This means that the renegotiation process with prior creditors takes place when the company is under time pressure. If the company fails to renegotiate its contracts before it reaches financial distress, it will be in default with some of its creditors. Thus, time pressure reduces the negotiating power of the company, since the party more pressured to complete the negotiation is usually the one which agrees to less favorable terms. In other words, the threat of financial distress reduces the company's capability of completing the renegotiation processes that are necessary to shift the company's assets back to productive activity.

\section{E. The Justification of Coercive Interference with Existing Entitlements}

When the company engages in inefficient entitlements, these entitlements burden the otherwise productive business activity. Efficiency requires that the assets be severed from these entitlements. ${ }^{86}$ If the parties cannot arrive at this solution by negotiation and contract, some alternative procedure must exist to impose this solution on the parties. Otherwise, perpetuated inefficiencies would increase the losses incurred by the inefficient entitlements.

\section{THE ROLE AND CONTENT OF BANKRUPTCY LAW}

\section{A. General}

We can now present the conditions for the commencement of bankruptcy,

86. The reader may wonder how to distinguish between "assets" and "entitlements." In the legal context, the two concepts seem to overlap, because the one party's contractual entitlement against some other contractual party may be a part of his or her assets, and vice versa. In the economic context, the two concepts are separate: assets exist in the world, in disregard of their distribution to human beings. Thus, one may identify these assets by exploring their existence, in a world where the concepts of rights and possession do not exist. If the asset in question would have continued to survive in the absence of personal rights and possessions, then it is an asset, and not merely an entitlement. If, on the other hand, the asset in question would have disappeared, together with all personal rights and possessions, then it only reflects an entitlement. 
and the role of bankruptcy law itself. This Article's main claim is that the satisfaction of three conditions will justify the severing of the company's assets from its existing arrangement of liabilities. The aim of collective collection proceedings is to bring about this essential severance, whether by way of reorganization or by way of liquidation, so as to reinstate the company's assets back to productive activity.

The three conditions are:

1. The company's existing arrangement of liabilities leads to inefficient exploitation of its resources;

2. The inefficiency cannot be solved through private agreement; and

3. The company is experiencing financial distress.

Each condition must be satisfied in order to justify the utilization of collective collection proceedings. ${ }^{87}$ Firstly, as long as the arrangement of liabilities is efficient, there is no reason to change it. In such a case, efficiency considerations and an interest to preserve the autonomy of the individuals justify the continuance of the existing arrangement of liabilities.

Secondly, as long as the parties can solve the inefficiency through their own agreement, there is no reason to seek an alternative course of action. The agreed-upon solution is superior to a collective proceeding since it is expected to be more efficient than a collective proceeding, and because it more accurately reflects the parties' desires. The private solution is more efficient because it involves lower costs than a lengthy collective proceeding. In addition, the parties will be superior to an external body in designing a new arrangement of liabilities that reflects their particular needs. The agreed-upon solution also preserves the parties' autonomy since it does not involve the element of coercion that characterizes the collective proceeding.

Finally, the condition of financial distress is vital, since any financial condition short of distress would represent the span of time in which management may attempt to find a solution to the inefficiency problem by itself. According to the agreements drawn up by the parties at the outset, control of the company is given to the shareholders and their representatives. Among other things, their powers consist of the ability to change the existing arrangement of liabilities, if such a change is deemed necessary. In this regard, they have the power to conduct negotiations with each and every one of the company's investors to change the conditions of the existing contracts. As long as the company is successful in paying its debts on time, there is no need for the court or any of the creditors to intervene. The company's experiencing of financial distress, however, indicates management's failure to reach an agreedupon solution, and thus constitutes the point at which the company's creditors will be the ones who bear the costs of the failure to reach an agreed-upon

87. In other words, the three conditions are essential. 
solution. Therefore, the point of financial distress is the suitable moment from which the responsibility for changing the existing arrangement of rights should be transferred from the controlling shareholders to the court and the trustee.

The existence of the three conditions is sufficient to justify the opening of collective collection proceedings. Firstly, the combination of the inefficiency and the financial distress justifies the change of the existing arrangement of liabilities, so as to reinstate the assets back to productive business activity. The financial distress leads the company into a state in which the burdens of its original arrangement of liabilities call its continued existence into doubt. Any attempt to continue the company's activity without change will necessarily involve violating some of the original liabilities. Thus, if the company is to survive, then the existing arrangement of liabilities will change regardless of whether the company affirmatively makes any changes, since the company's breaching of some of its liabilities would amount to an effective rearrangement of its liabilities (hereinafter the "factual progression"). At this point, redesigning the existing arrangement of liabilities through a collective proceeding is preferable to doing so through the factual progression, which would develop as a result of the creditors' desperate attempts to collect their debts.

Secondly, in light of the failed attempt to reach an agreed-upon solution without a collective proceeding, the element of coercion becomes inevitable. Coercion can take a number of forms. The first possibility is that the trustee may force the parties to release the assets from the existing arrangement of liabilities. Alternatively, the previous paragraph's factual progression could bring about a coercive change of the creditors' rights as well. The best form of coercion is through a court-ordered solution, because a court's solution is likely to be no more coercive than necessary to achieve the objective at hand.

Finally, in order to reinstate efficient use of the company assets, it is essential that the changes in existing entitlements be managed by a third party, such as the trustee, and not by the company's controlling shareholders or by some of the creditors. Otherwise, the transformation of existing entitlements would be tuned to the interests of particular investors rather than to aggregate efficiency. ${ }^{88}$

88. Indeed, Baird \& Rasmussen have shown that a critical phase of the collective proceedings concerns the shift of control from the shareholders' representatives to the trustee. See Baird \& Rasmussen, supra note 29. See also Henderson v. Casciato-Northrup, 2001 U.S. Dist. LEXIS 23637, at * 15 (Bankr. W.D. Tex. Jan. 10, 2001); Correll v. Equifax Check Servs., 234 B.R. 8, 10 (Bankr. D. Conn. 1997); In re Harris, 200 B.R. 745, 747-48 (Bankr. D. Mass. 1996); In re Gray, 28 B.R. 348, 349 (Bankr. S.D.N.Y. 1983), In re Derickson, 226 B.R. 879, 881 (Bankr. S.D. Ill. 1998); In re Reid, 179 B.R. 504, 507 (Bankr. E.D. Tex. 1995). 


\section{B. The Essence of Collective Collection Proceedings}

Collective collection proceedings release the company's assets from the existing arrangement of liabilities, so as to return the assets back to productive business activity. The liquidation or reorganization proceedings usually feature one or more of the following means to transform the existing arrangement of rights: ${ }^{89}$

a. Changing the structure of the commitments: The discharge from prior entitlements must focus on the right side of the company's balance sheet. The company's business will continue operating normally, such that the company will remain a going concern; however, the collective proceedings will lead to a reorganization of the claims against the company. Thus, for example, in the event that the company reaches insolvency due to its leverage ratio, the capital structure will have to be reorganized in such a way that some of the fixed liabilities will be replaced by share equity. For this purpose, the collective proceedings erase some of the debts, and some of the creditors will receive preferred or common stock in lieu of their original claims of debt. The creditors would receive an amount of shares that would appropriately reflect the riskier nature of share ownership.

Lowering the interest rates on the loans is another way to change the structure of the capital. Alternatively, the company can obtain new credit during the proceedings to pay off the old loans, and the capital structure would change to include the new debt on the company's books. Finally, any changes in the employment contracts with the company's workers would also fall into this first category.

b. Changing the structure of control: Once the company enters into the liquidation or reorganization proceedings, the creditors seize control of the company's assets from management. Once the collective proceedings begin, the structure of control of the assets will never return to its original state. If, for instance, the company undergoes liquidation, then its assets will be transferred to the ownership and control of other businesses; and if the company undergoes reorganization, then the resulting lower value of the business will prevent the original shareholders from enjoying their previous degree of control. ${ }^{90}$

c. Selling the assets: The most drastic form of severing the company's assets from its prior liabilities is when the company sells its assets to third parties. Selling the assets causes a change in the existing arrangement of liabilities because it severs the pre-liquidation link between the assets and the

89. These changes are depicted in Warren's article. See Warren, Bankruptcy Policy, supra note 3, at 785-86. Although Warren presents bankruptcy law as a procedural process for collecting debts that constitutes an alternative to the states' individual collection proceeding, she points out that bankruptcy law changes the existing arrangement of rights. Warren emphasized with particularity the change that the existing arrangement of rights undergoes when it enters collective collection proceedings.

90. See Baird \& Rasmussen, supra note 29 , at 948. 
company's shareholders and creditors. In place of this original link, a new ownership relationship emerges between the assets and the buyer. When the assets are sold as a "going concern," all of the assets become the property of a single buyer. When the sale is done "piecemeal," the assets are distributed to different buyers. Regardless of how the sale is carried out, the original ownership link is severed.

Reorganization typically features the first two categories, while liquidation features the third category. The type and level of severance of the company's assets from its initial entitlements should depend on the sources of inefficiencies. The basic guideline is to minimize the impediment of existing entitlements, and thus, to avoid using an unnecessary type of severance. For example, if the company reaches financial distress only because of its leverage ratio, it should undergo reorganization proceedings to design a feasible capital structure. There is no reason to sell the assets to third parties. ${ }^{91}$ Similarly, if the source of failure is rooted in the company's control, then the incumbents must be replaced. However, this shift of control should not lead to any alteration of the debt liabilities, nor should the company be sold to third parties.

\section{CONCRETE ARRANGMENTS OF BANKRUPTCY LAW}

\section{A. The Choice between Reorganization and Liquidation}

Previous parts have discussed the conditions under which there is a normative justification to sever a company's assets from the arrangement of liabilities that was created in relation to those assets. This Article has yet to explore the correct way to release the assets from the existing rights. First, what should the default procedure be: reorganization or liquidation? Second, what policy considerations should guide the selection between these two options?

Positive law does not mandate a bankruptcy court to explicitly examine the choice between reorganization and liquidation. Initially, the party who files the bankruptcy petition also elects one of the proceedings. ${ }^{92}$ For instance, the debtor may file a petition for commencement together with a reorganization plan. Then, the Bankruptcy Code provides the debtor with a period of 100-180 days to secure plan confirmation. ${ }^{93}$

Once the proceedings begin, the creditors are stayed from collection efforts, ${ }^{94}$ and the debtor has a chance to reorganize the business. This statutory arrangement implicitly prefers reorganization-because the debtor or the

91. See infra Part IV.A.

92. However, soon after commencement, the fate of a reorganization effort is determined by the capability of the trustee to obtain new credit in order to cover the ongoing expenses of the going concern. See infra Part IV.B.

93. This period may be extended. See 11 U.S.C. $\S 1101$ (2000). Additionally, 11 U.S.C. $\S 362$ stays the foreclosure of security interests for nine months.

94. 11 U.S.C. $\S 362(2000)$. 
shareholders of the bankrupt firm would usually prefer reorganization, they often preempt their creditors by voluntarily filing a petition. Once they succeed in staying the collection proceedings for 100-180 days, they also gain a strong negotiation position that facilitates the enforcement of reorganization on all of the other creditors. ${ }^{95}$ Indeed, the trustee and the bankruptcy court specifically confront and address the sources of inefficiency that had led the firm into financial distress when they deal with issues such as the feasibility of the capital structure, or the adequate protection of secured creditors. ${ }^{96}$ Nevertheless, the bankruptcy court is not required to condition the choice between reorganization and liquidation on an inquiry into the sources of inefficiency. As a result, many firms undergo reorganization proceedings even when the circumstances of the particular case may call for liquidation. ${ }^{97}$

On the other hand, traditional law-and-economics supports liquidation over reorganization. ${ }^{98}$ In his Uneasy Case of Corporate Reorganizations, Professor Baird presented the possibility (and its reported advantages) of selling the bankrupt going-concern to a third party in liquidation proceedings as a justification for reformulating the choice between the two options. ${ }^{99}$ Traditionally, corporate liquidations were associated with selling the corporate assets piecemeal, whereas corporate reorganizations were associated with maintaining the going concern. Accordingly, reorganization was the better choice when the value of the going concern was higher than the sum of its individual parts. Nevertheless, as Baird indicated, if the going concern can be sold in liquidation proceedings, then its excess value cannot be deemed sufficient to support reorganization, because the realization of the higher value would not be unique to reorganization. ${ }^{100}$ On the contrary, because reorganizations involve the allocation of new claims against the uncertain value of the reorganized firm, they inherently involve some form of redistribution and avoidance of existing entitlements. Thus, liquidations always remain more efficient than reorganizations-they succeed in providing the same aggregate value, and do so without violating prior entitlements. ${ }^{101}$ Baird suggested perceiving reorganizations as hypothetical sales of the company's assets to their initial investors. The company should undergo reorganization only when the

95. See Bebchuk \& Chang, supra note 51 .

96. See infra Part IV.B.

97. See Lynn M. LoPucki, The Debtor in Full Control - Systems Failure Under Chapter 11 of the Bankruptcy Code?, 57 AM. BANKR. L.J. 99 (1983).

98. Reorganizations involve tremendous costs. See Stephen J. Lubben, The Direct Costs of Corporate Reorganization: An Empirical Examination of Professional Fees in Large Chapter 11 Cases, 74 AM. BANKR. L.J. 509 (2000); Stephen J. Lubben, Some Realism About Reorganization: Explaining the Failure of Chapter II Theory, 106 DICK. L. REv. 267 (2001); Kevin A. Kordana \& Eric A. Posner, A Positive Theory of Chapter 11, 74 N.Y.U. L. REV. 161 (1999).

99. See Baird, supra note 26.

100. Id. at 129.

101. Id. 
initial investors are willing to invest the highest value in the business.

Bebchuk \& Chang focused on the bargaining power of the shareholders in reorganization proceedings, which derives from their power to stay the collection proceedings for at least nine months. ${ }^{102} \mathrm{~A}$ nine-month delay may force senior creditors to surrender portions of their initial entitlements. ${ }^{103}$ Accordingly, Bebchuk \& Chang suggested a legal arrangement that would allow the parties to opt-out of the reorganization option ex ante, at the time of contracting. ${ }^{104}$

Finally, the recent The End of Bankruptcy points to the practical transformation of reorganization proceedings. ${ }^{105}$ In this essay, Baird \& Rasmussen claim that contemporary reorganizations no longer involve the rehabilitation of failed businesses, but rather they become a source of opportunity for the shareholders to sell their business to a third party for a better price. ${ }^{106}$ Baird \& Rasmussen suggest that because the initial justification of reorganizations no longer holds, bankruptcy law should instead enforce the pre-existing contracts. ${ }^{107}$

The theory presented in this Article does not support the positive law's implicit inclination towards reorganization, nor does it follow the law-andeconomics preference for liquidation. This new theory calls for a legal arrangement that would mandate a preliminary hearing, at which the bankruptcy court would have the discretion to select the appropriate proceeding for the particular case. This judicial hearing would save the costs involved in futile reorganization efforts, and would ensure that judicial proceedings target the sources of inefficient entitlements.

For example, while the legal system may help in solving the first and second sources of inefficiency, it cannot solve the third. ${ }^{108}$ In other words, the court can effectively implement a reconstruction of current liabilities, an avoidance of burdensome contracts, and a change of control, but the legal system cannot affect in any way the demand for the corporation's products, or the costs of production. Accordingly, liquidation is the only solution for the third source of inefficiency.

The remaining question concerns the legal choice between reorganization and liquidation in bankruptcy cases that emerge from the first and second

102. See Bebchuk \& Chang, supra note 51.

103. To prove this claim, Bebchuk \& Chang present a bargaining model, which shows that in order to save the cost of delay, senior creditors might be willing to surrender portions of their claims on behalf of junior creditors. In this manner, the senior creditors encourage the junior ones to support the reorganization plan at earlier dates. Id.

104. Id.

105. See Baird \& Rasmussen, supra note 2.

106. Id. at 777-78.

107. This factual assertion remains controversial. See the reference to LoPucki's empirical findings, supra note 33 .

108. For a detailed discussion of the three sources of inefficiency, see supra Part II.B. 
sources of inefficiency. In these cases, traditional law-and-economics doctrine calls for liquidation proceedings in order to avoid the redistribution effects of reorganization. ${ }^{109}$ As Baird indicated, liquidation can maintain the pre-petition business activity when the company is sold as a going concern. ${ }^{110}$

The present theory challenges this argument, and calls for a more refined choice between the two types of procedures. The following discussion develops this argument in two stages. First, I will show that it is incorrect to assume that reorganizations involve a more far-reaching avoidance of existing entitlements. The analysis will show that both types of procedures result in the severance of the bankrupt estate from pre-petition entitlements. Second, I will show that each procedure's degree of coercive interference with existing entitlements is case-specific. In some cases, reorganizations would yield a more severe impact on existing entitlements, whereas in others, reorganizations would better preserve the initial scheme of distribution.

To understand this point, one must note that the pre-petition arrangement of liabilities involves two types of relationships:

a. The relationships between the assets and the contracting parties: Prepetition entitlements entail legal relationships between the company's assets and its shareholders and creditors. For example, existing entitlements provide the shareholder who holds over $50 \%$ of the company shares the right to control its assets. Similarly, existing entitlements define the identity and authority of each of the company's employees, and thereby entail the actions that each employee would perform on behalf of the company. These actions affect the assets and their value. Finally, the company's property interest in its assets excludes other potential holders from having any proprietary rights in those resources.

b. The relationships between the contracting parties themselves: The existing entitlements also entail a distributive scheme among the company's investors. For example, traditional priority orders entail that the shareholders hold the residual claim against the company's assets. This implies that the creditors are entitled to be paid in full before the shareholders gain any positive value. Similarly, the law states that secured creditors are entitled to be paid in full before the unsecured creditors recover any positive value. ${ }^{111}$ (See Figure No. 2.)

109. See Bebchuk \& Chang, supra note 51.

110. See Baird, supra note 26.

111. See Jackson \& Kronman, supra note 13. 
2.a. The First Type of Relationship: Existing entitlements yield a function from the set of the company investors to its set of assets:

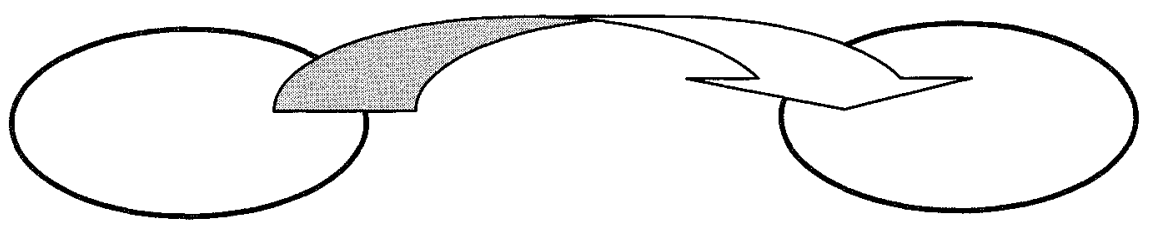

The set of investors

The set of assets

2.b. The Second Type of Relationship: Existing entitlements yield a distribution scheme among the company investors:

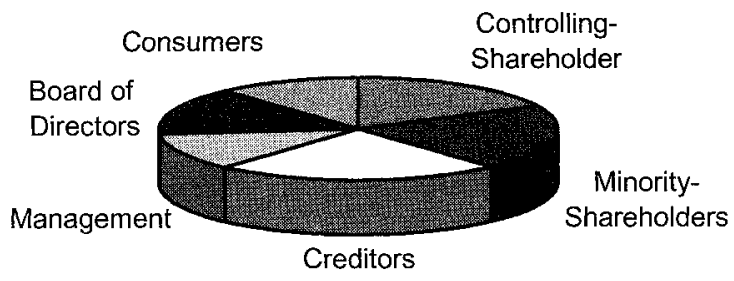

Liquidations involve a more far-reaching avoidance of the first type of relationships - in reorganizations, at least some of the initial investors would continue to hold claims against the company assets. In reorganizations, the company's shareholders and bondholders would hold new securities against the reorganized company, portions of the company employees would continue to work for the reorganized firm, and suppliers and dealers would continue to work with the company. Liquidations, on the other hand, would terminate these relationships, because the assets would be sold to a third party. ${ }^{112}$

Reorganizations involve a more far-reaching intervention with the second type of relationships, that is, the relationships among the company's investors. Because reorganizations violate the absolute priority rule, they yield a

112. For the emphasis on firm-specific relationships as a justification for reorganization, see LoPucki, supra note 12. From this viewpoint, the perception of reorganization as a "hypothetical sale" of the corporation's assets to their initial owners is flawed. This perception assumes that the assets were already fully detached from their owners, and then turns to explore the adequate way to sell the detached assets to the highest bidder. It is dubious, however, why the assets should be detached from their initial investors and owners in the first place. 
redistribution of the initial claims against the company's assets. ${ }^{113}$

The level of interference with existing entitlements changes from one case to another. In some cases, liquidations would cause more interference than reorganizations, and vice versa. Therefore, in selecting between the two options, the court must exercise its discretion, and adapt the decision to the particular circumstances of the case. In particular, the following policy considerations must be taken into account:

a. The source of inefficient entitlements: The judicial examination must begin with an inquiry into the sources of inefficient entitlements. When dealing with the third source of inefficiency, the court must order liquidation. Otherwise, the court must turn to apply the remaining policy considerations.

b. The feasibility of acquisition by a third party: The abstract law-andeconomics approach presumes that the trustee would always be able to find a third party buyer for the corporation's assets (whether individually or as a going concern). This presumption does not always hold. In many concrete cases, there is no potential buyer who is willing to pay a reasonable price for the bankrupt business or its individual components. In such cases, the only option for maintaining the going concern value is reorganization. Therefore, the trustee must seek potential buyers prior to the court's decision between liquidation and reorganization. If the trustee finds a third party buyer, the court should order liquidation. ${ }^{114}$ Otherwise, the court must continue exploring the choice between reorganization and liquidation, and should select the option that can be realized in the shortest period of time, given the constraints of the remaining policy considerations.

c. The uncertainty involved in the reorganization plan: While all reorganizations involve some level of deviation from the absolute priority rule, the degree of avoidance of existing entitlements changes from one case to another. Accordingly, in considering a reorganization plan, the court must take into account the level of uncertainty involved with the post-reorganization value of the going concern. The greater the uncertainty involved with the reorganization plan, the less favorable this option becomes. High risks should be deemed sufficient for dismissing a reorganization plan.

d. The level of cooperation by the shareholders and management: Because reorganizations can succeed only upon the full cooperation of existing management and shareholders, the court should take into account their willingness to invest further human and financial resources in the reorganization plan.

e. The feasibility of new credit in reorganization: As the discussion below

113. See Baird, supra note 26 .

114. Note, however, that none of these considerations is determinative on its own. For example, even when the trustee finds a third-party buyer, it may still be that the sale to the third party through reorganization proceedings yields a higher value than the sale in liquidation. 
will demonstrate, the best measure of the feasibility of a reorganization plan is the willingness of new investors to provide the company with new financing during the reorganization proceedings. Accordingly, the likelihood of obtaining new financial resources should also guide the court in selecting between reorganization and liquidation.

f. The proportionality test: Finally, if none of the above tests fully determines the judicial choice of procedure, the court must turn to apply some flexible balancing test. The court must balance the costs of inefficiencies that would result from terminating the relationships between the company investors and the assets in liquidation, against the costs of inefficiencies that would result from violating the absolute priority rule in reorganization. The results of this balancing test would change from one case to another.

\section{B. Obtaining New Credit in Reorganizations ${ }^{115}$}

A company commences bankruptcy proceedings due to financial distresswhen it fails to obtain necessary funding for its current activity because its shareholders and management can no longer attract new investment. When the bankruptcy proceedings begin, the trustee must find ways to acquire new credit for the bankrupt business. On many occasions, the capability of the trustee to obtain new credit determines the practical feasibility of reorganization. Bankruptcy law facilitates the acquisition of new credit by enabling the trustee to provide the new investor with a senior position: the trustee can provide the new creditor with the preferential position of "administrative expenses," "116 provide the creditor a lien on the property of the estate. ${ }^{117}$ As long as the new credit is obtained in the ordinary course of business, the trustee has the authority to act without judicial approval. However, when the acquisition of the new credit is beyond the ordinary course of business, the trustee must turn to the bankruptcy court for approval. ${ }^{118}$

The judicial interpretation of section 364 developed two tests to determine whether credit is obtained in the "ordinary course of business":

The first test is the creditor's expectation, [or]. . the "vertical" test. It asks whether a reasonable creditor would view the transaction as deviating from the debtor's normal day-to-day operations. ... The counterpart. . is the "horizontal" test, [which]. . .compares the debtor's business with other like businesses to determine whether the disputed transaction is ordinary for the particular type of business concerned. $^{119}$

115. Nicholas L. Georgakopoulos, New Value, Fresh Start, 3 STAN. J.L. Bus. \& FIN. 125 (1997).

116. 11 U.S.C. $\S 364$ (2000).

117. Id.

118. See § 364(b).

119. In re Blessing Indus., 263 B.R. 268, 272 (Bankr. N.D. Iowa 2001); see also Rajala v. Langer, 259 B.R. 728, 732-33 (Bankr. D. Kan. 2001); In re Ockerlund Constr. Co., 308 B.R. 325, 329-30 (Bankr. D. Ill. 2004); In re Atlanta Retail, 287 B.R. 849, 856-57 (Bankr. N.D. Ga. 2002). 
The bankruptcy courts decline to approve the preferential position of the new creditor retroactively, when the new credit exceeds the ordinary course of business, ${ }^{120}$ unless the court finds that the retroactive order will further the purposes of the Bankruptcy Code without unfairly prejudicing parties-ininterest. $^{121}$

The preferential position of post-petition creditors exemplifies the role of bankruptcy law. As long as the company is active, it is required to fulfill its liabilities in their entirety. Every new creditor who agrees to transfer new credit to the company does so as an aggregate to the existing debts. The new creditor knows that the company will be required to pay both its new debt and its other debts to preceding creditors. At a certain point, new potential creditors will fear the possibility that the company's income will not suffice to pay the liabilities toward them and toward the preceding creditors. Similarly, potential investors in the company's shares will fear that the existent burden of debts will drain the company's income, thus leaving no remaining source of value for the shareholders.

The commencement of bankruptcy severs the debtor's assets from his or her pre-petition liabilities, and thereby enables the trustee to use the bankrupt's assets to secure the repayment of post-petition credit. Once the business obtains the necessary financial resources, it can return to productive activity. To this end, the trustee does not have unlimited powers to obtain new credit and to provide the new creditor with priority over pre-petition creditors. The trustee may obtain the new credit only when new financial resources are essential for increasing the value of the estate, that is, when the attainment of new financial resources is supported by efficiency considerations.

The power of the trustee to provide the post-petition creditors with a preferential position highlights the conflict between pre- and post-petition creditors. While the post-petition creditor would insist on acquiring some form of seniority, pre-petition creditors may oppose the new credit transaction because it diminishes the value left for the repayment of their debts. Section 364 of the Bankruptcy Act resolves this conflict by subordinating the trustee's power to the adequate protection of pre-petition holders of security interests. ${ }^{122}$ The following examples demonstrate how the actual legal arrangement depends on the judicial interpretation of the concept of adequate protection: ${ }^{123}$

1. Assume, for example, that the trustee seeks to provide the new creditor with superior security interest, and that the prior secured creditors are over-

120. See Rajala, 259 B.R. at 733-34.

121. For the doctrine of the nunc pro tunc relief, see In re Hillard Dev. Corp., 2004 Bankr. LEXIS 931, at *3 (Bankr. S.D. Fla. Apr. 16, 2004); In re Lehigh Valley Prof'1 Sports Clubs, Inc., 260 B.R. 745, 750 (Bankr. E.D. Pa. 2001).

122. 11 U.S.C. $\S 364(d)(1)(B)$.

123. Adequate protection is defined in 11 U.S.C. $\S 361$ (2000). 
secured. Let the value of the collateral that serves to secure both the prepetition and post-petition creditors be $\$ 1$ million; let the pre-petition secured debt be $\$ 500,000$, and let the value of the new loan be $\$ 500,000$. A pre-petition creditor opposes the trustee's plan to provide the new creditor with a superior lien, on the grounds that it would diminish the value of its security interest, in violation of the adequate protection requirement.

In In re Shaw Industries, ${ }^{124}$ the bankruptcy court dealt with a similar set of facts, and ruled for the pre-petition secured creditor. The court found that even though the pre-petition creditors were over-secured, the new superior security interest would increase the risk that the pre-petition creditor would not be paid in full, since the court agreed with the pre-petition creditor's expectation that the collateral's value would decrease over time. ${ }^{125}$

2. Assume for example, that the trustee desires to shift the initial security interest from one source of collateral to another, in order to provide the new creditor with a superior security interest in the initial collateral. ${ }^{126}$ Let the value of the initial collateral be $\$ 1$ million, and let the pre-petition secured debt be $\$ 500,000$. The trustee obtains a new loan in the value of $\$ 500,000$, and is willing to provide the new creditor with a superior security interest. For this purpose, the trustee shifts the pre-petition security interest to an alternative source of estate collateral that is worth only $\$ 600,000$. A pre-petition creditor opposes this shift, on the grounds that it increases the risk that the value of the collateral would not be sufficient to cover the pre-petition secured debt in its entirety, in violation of the adequate protection requirement.

These two examples illustrate three possible approaches to the adequate protection requirement. The first approach follows the decision in In re Shaw Industries, where the court applies the requirement to elevate the interest of pre-petition creditors over the trustee's interest in obtaining new credit. This approach would limit the trustee's ability to avoid existing entitlements, even though such limits may obstruct the reorganization process. Accordingly, in the first example, the court would prevent the trustee from providing the postpetition creditor with a superior lien, even when the pre-petition creditors are over-secured. In the second example, a court using this first approach would prevent the shift of security interest from one source of collateral to another, unless the value of the new collateral is equal to or greater than the value of the

124. 300 B.R. 861 (Bankr. W.D. Pa. 2003).

125. For example, following the above numerical example, if the collateral's value decreases below $\$ 1$ million it can no longer cover both debts. Thus, if the new security interest is superior to the prepetition one, then the initial creditor would no longer be repaid in full. Similarly, when the two debts continue to accumulate post-petition interest, then the value of the new debt is expected to increase to above $\$ 500,000$. Thus, if the new creditor enjoys an absolute priority over the initial one, the remaining value that would be left after the new creditor is paid in full would not be sufficient to cover the initial debt.

126. The possibility of providing adequate protection via a "replacement lien" is fixed in 11 U.S.C. $\S 361(2)(2000)$. 
initial collateral. ${ }^{127}$ The advantage of this approach is that it succeeds in protecting pre-petition entitlements, and thereby encourages parties to plan efficient credit transactions at the time of contract, well before the business goes bankrupt. The problem with this approach is that it diminishes the trustee's ability to employ all existing sources of value for the purpose of obtaining new credit. In both examples, the trustee would not be able to use the difference between the value of the collateral and the value of the pre-petition debt to secure the repayment of post-petition credit. Thus, the trustee may unnecessarily fail in his efforts to reorganize the bankrupt business.

The second possible approach would limit the adequate protection requirement to the value of the pre-petition debt at the date of commencement. In the above examples, it would suffice for the trustee to maintain at least $\$ 500,000$ of security interest on behalf of the pre-petition creditors. ${ }^{128}$ Thus, in the first example, the trustee would be able to provide the new creditor with a superior lien on the collateral because the collateral's value would still cover the pre-petition debt of $\$ 500,000$. In the second example, the trustee would be able to shift the initial creditor from the initial source of collateral to an alternative one, as long as the alternative collateral's value exceeds $\$ 500,000$. This approach facilitates the capability of the trustee to rearrange the prepetition security interests, and thereby maximize the remaining value for securing the repayment of new credit. However, this approach involves a farreaching interference with prior entitlements, and as such, threatens the capability of pre-petition creditors and solvent businesses to pre-plan their credit transactions.

This Article's theory of bankruptcy law supports a third approach to the adequate protection requirement. Under the third approach, adequate protection entitles the pre-petition secured creditor to a value equal to the value he would have received had the collateral been foreclosed immediately upon the commencement of bankruptcy proceedings. In the above examples, the security interest should continue to cover both the value of $\$ 500,000$, and the market cost of delay, or post-petition interest calculated according to the market interest rate. Assume, for example, that following reorganization, the postpetition creditor would recover his debt only five years after commencement.

127. Similarly, in In re Waste Conversion Techs., Inc., 205 B.R. 1004 (Bankr. D. Conn. 1997), the bankruptcy court ruled that the replacement lien must provide full compensation. Thus, when the initial lien is fully perfected, the creditor is entitled to automatic perfection in the replacement lien as well. See also In re Martin, 761 F.2d 472 (8th Cir. 1985).

128. This is the accepted judicial interpretation of adequate protection in the context of undersecured creditors, and creditors whose collateral only covers the value of the debt at the date of commencement. In United Savings Ass'n. v. Timbers of Inwood Forest Assocs., Ltd., 484 U.S. 365, 37273 (1988), the Supreme Court held that adequate protection does not mandate the preservation of a cushion for covering the post-petition interest when the initial collateral covers the debt value at the date of commencement. This decision was distinguished by several later decisions, but never expressly overruled. See, e.g., LNC Invs., Inc. v. First Fid. Bank, 247 B.R. 38 (Bankr. S.D.N.Y. 2000). 
Also, assume that the market interest rate is $8 \%$. Then, adequate protection requires that the collateral continue to secure the value of $\$ 586,660$ for the prepetition creditor. Then, in the first example, the new secured credit cannot exceed the value of $\$ 413,340$. In the second example, the alternative collateral must preserve the value of $\$ 586,660 .{ }^{129}$

The third approach accomplishes both the purpose of severing the bankrupt's assets from prior inefficient entitlements, and the purpose of protecting the pre-planning of credit transactions. Following this third approach, the acquisition of new credit in reorganizations would become a quasi-monitoring mechanism, which enables only the companies worthy of reorganization to undergo reorganization. To see how this works, consider that reorganization is appropriate only when the value of the company's assets in reorganization is higher than their value in liquidation. In order for the reorganization plan to be efficient, it must ensure its investors a higher value than they can obtain in the market, in exchange for investing money that the company would have received had it immediately sold its assets in liquidation. Thus, for example, if the value of the company's assets in an immediate sale is 100 , and the market interest rate is $8 \%$, then reorganization will be advantageous only if the future income of the company is expected to exceed an $8 \%$ rate of return. Otherwise, it is advisable to dissolve the company, sell its assets in exchange for 100 , and enable its creditors to enter alternative investments with the money that they will receive when the company sells its assets.

Assume, for example, that all of the company's existing assets serve as collateral to pre-petition secured debt. According to the third approach, the trustee will be forced to supply the secured creditors with a value of 100 plus an annual interest of $8 \%$, such that he will not be able to grant any sort of preference to the new creditor. Finally, assume that the company requires new credit at the value of 20 . The new credit will raise the current value of the company's assets to 120 . However, the new creditor will require a security interest in something more than the new assets which the company obtained through the money from his loan, because he will fear that this security will cover only the value of his loan's principal, and not the interest as well. Therefore, he will agree to invest only if the company's income will have an annual yield exceeding 8 percent. In other words, the new creditor will not be

129. This approach is supported by many jurisdictions. See, e.g., In re Park West Hotel Corp., 64 B.R. 1013 (Bankr. D. Mass. 1986) (holding that the debtor's burden is to show not only that the market value of the property, less costs of sale and tax encumbrances, is greater than the steadily increasing amount of the secured party's debt, but also that it is greater by a margin sufficient to ensure that the secured party's interest is not at risk); see also In re R \& H Inv. Co., 46 B.R. 114 (Bankr. D. Conn. 1985); In re Kertennis, 40 B.R. 895 (Bankr. D.R.I. 1984); In re Heath, 79 B.R. 616 (Bankr. E.D. Pa. 1987); Anchor Sav. Bank v. Sky Valley, Inc., 99 B.R. 117 (Bankr. N.D. Ga. 1989); In re Mellor, 734 F.2d 1396 (9th Cir. 1984). 
prepared to invest in the company unless he expects the company's business to yield a higher return than he can obtain on the market. In this way, the trustee will be able to meet the adequate protection conditions towards the previous creditors, in addition to ensuring the new creditor's sources of payment.

The company's ability to raise new credit during reorganization acts as an extremely important monitoring mechanism. At the stage of examining the reorganization plan, it is uncertain whether reorganization would be advantageous. The court's decision is a result of valuation formulae, which rely on the future hypothetical values of the reorganized company. ${ }^{130}$ Valuation techniques enable much flexibility and may lead to substantial variances in the possible results. Different interested parties will try to distort the results of the assessment by arguing for certain valuations, so as to persuade the court to adopt a procedure in accordance with their personal interests.

Thus, when reorganization is the action taken, it is expected that a group of claimants (for example controlling shareholders, managers of the company, or regular creditors) will ask for a piece of the reorganization yield. Such a group will suggest reorganization plans, which are based on optimistic assessments of the expected revenue of the company, only because the group would profit more from any of its plans than from liquidation. However, when reorganization yields the same value as liquidation, then reorganization harms, rather than benefits, the company's creditors. This is so because reorganization involves considerable costs, which are necessary in order to keep the company active during the collective proceedings, to postpone the payment of the debts, and to entice new creditors to invest in the failing company. Therefore, it is important that the trustee be limited in raising new credit for the reorganization. Adequate protection for the previous secured creditors will ensure that the raising of credit will be done only when there are investors who believe that the company's return will be greater than that of the market.

\section{Executory Contracts}

The treatment of executory contracts most clearly exemplifies the role of bankruptcy law. ${ }^{131}$ A company not in bankruptcy cannot be released from the commitments it created, even if the commitments turn out to be unprofitable. After the commencement of bankruptcy proceedings, the trustee is entitled to choose between performance and avoidance of pre-petition contractual

130. See Bebchuk, supra note 51, at 777-81.

131. See 11 U.S.C. $\S 365(2000)$. Section 365 grants the authority to the liquidator or the trustee to choose whether to assume, assign or to reject an executory contract. Executory contracts are contracts in which both parties, the company and the second party to the contract, have not yet performed all of their commitments. See In re Riodizio, Inc., 204 B.R. 417, 424 (Bankr. S.D.N.Y. 1997); In re Parkwood Realty Corp., 157 B.R. 687, 689 (Bankr. W.D. Wash. 1993); Vecchitto v. Vecchitto, 2000 U.S. App. LEXIS 25439 (2d Cir. Oct. 11, 2000). 
obligations. If the trustee elects to perform the contract, then both parties (the bankrupt estate and the other contractual party) would have to abide by the prepetition liabilities. If the trustee chooses avoidance, then the estate would not perform its duties under the contract, and the other parties would be forced to share the value of the estate with the other non-secured creditors. ${ }^{132}$

In order to clarify the practical meaning of this arrangement, it is important to note the different stages that the company's contracts can be found at the beginning of the collective proceedings:

a. Either early stages of performance or continuous contracts: It is possible that the company entered into the contract, but that neither party has yet to perform the majority of the contractual obligations involved in it. A similar possibility is that both parties have already partially performed the contract, but that it is a continuous contract, such that both parties are committed to implementing different commitments over a period of time. In either possibility, the collective proceedings will have begun at a time when there are still many obligations that the parties have not yet performed.

b. Intermediate stages of performance: It is possible that the creditor has already fully performed its obligations towards the company, but that the company has not yet fully performed its obligations towards the creditor.

c. Intermediate stages of performance: It is also possible that the company has already fully performed its obligations towards a third party, but that the third party has not yet fully performed its contractual obligations towards the company.

d. Advanced stages of performance: Finally, it is possible that both parties have fulfilled the majority of their mutual contractual commitments.

In contracts in which the creditor has fully performed but the company has not, the trustee will avoid fulfilling the company's obligation towards the creditor when the creditor can claim its debt in collective proceedings. ${ }^{133}$ In contracts where the company has fully performed but a third party has not, the trustee will be able to file for performance on behalf of the estate. Finally, where both parties have fully performed their contractual obligations, the collective proceedings do not affect the parties' rights. ${ }^{134}$

Thus, the arrangement of executory contracts refers only to scenarios where both parties have yet to fully perform their contractual obligations. To be more precise, most bankruptcy courts have adopted Professor Countryman's definition of executory contracts: ". . . a contract under which the obligation of

132. 11 U.S.C. $\$ 363(2000)$.

133. There is a conflict on this issue as to how to classify option contracts. The leading approach is that options will not be considered executory contracts, unless the owner of the option decides to realize the option before submitting the request for bankruptcy. See, e.g., In re Robert L. Helms Constr. \& Dev. Co., 139 F.3d 702, 706 (9th Cir. 1998).

134. See In re Leefers, 101 B.R. 24, 26 (Bankr. C.D. Ill. 1989); In re Level Propane Gases, Inc., 297 B.R. 503, 507 (Bankr. N.D. Ohio 2003). 
both the bankrupt and the other party to the contract are so far unperformed that the failure of either to complete performance would constitute a material breach excusing the performance of the other." ${ }^{135}$ Once a court determines that a contract is executory, the law grants the trustee or liquidator the right to reexamine the profitability of the transaction from the point of view of the debtor-company. ${ }^{136}$ If the trustee determines that the company is better off if the parties were to carry out the terms of the contract, then the trustee must implement it. Otherwise, the contract should be perceived as an "unprofitable contract" that should be "avoided." 137 For example, if we are discussing a contract to purchase an apartment from a real estate company, where the real estate company filed for bankruptcy during the building process, then the trustee will have to estimate the proceeds that the company expects to receive from the buyer and compare it to both the costs of finishing the building and the cost of foregoing an alternative contract (in which the apartment will be sold to a different buyer). The trustee will choose to perform the contract only when the expected proceeds from the buyer are higher than these costs.

The following numerical example clarifies this situation (see Table No. 1 below):

135. See In re Knutson, 563 F.2d 916, 917 (8th Cir. 1977); see also In re Craig, 144 F.3d 593, 596 (8th Cir. 1998).

136. 11 U.S.C. $\S 363$.

137. See, e.g., In re Bradlees Stores, 194 B.R. 555 (Bankr. S.D.N.Y. 1996); In re David Orgell, Inc., 117 B.R. 574 (Bankr. C.D. Cal. 1990). 
Table No. 1: Examining the Existence of a Burdensome Asset

\begin{tabular}{|c|c|c|}
\hline & Numerical example & Denoted \\
\hline $\begin{array}{l}\text { Costs of completing the } \\
\text { building }\end{array}$ & 100 & $\overline{C_{b}}$ \\
\hline Balance due & 150 & $\mathrm{EP}_{\mathrm{c}}$ \\
\hline $\begin{array}{l}\text { Current market price of } \\
\text { the apartment }\end{array}$ & 400 & $\mathrm{~V}_{\mathrm{m}}$ \\
\hline $\begin{array}{l}\text { Value of implementing } \\
\text { the contract }\end{array}$ & $(150-100)$ & $\left(E P_{c}-C_{b}\right)$ \\
\hline $\begin{array}{l}\text { Transaction costs of } \\
\text { alternative contracts }\end{array}$ & 50 & TC \\
\hline $\begin{array}{l}\text { Value of alternative } \\
\text { transaction }\end{array}$ & $(400-100-50)$ & $\left(\mathrm{V}_{\mathrm{m}}-\mathrm{C}_{\mathrm{b}}-\mathrm{TC}\right)$ \\
\hline $\begin{array}{l}\text { The trustee's necessary } \\
\text { decision }\end{array}$ & $\begin{array}{l}\text { Since the value of } \\
\text { implementing the } \\
\text { contract is lower than } \\
\text { the value of the } \\
\text { alternative transaction, } \\
\text { the trustee must refrain } \\
\text { from executing the } \\
\text { contract. }\end{array}$ & $\begin{array}{l}\text { Max }\left\{\left(\mathrm{EP}_{\mathrm{c}} \cdot \mathrm{C}_{\mathrm{b}}\right),\left(\mathrm{V}_{\mathrm{m}} \cdot \mathrm{C}_{\mathrm{b}}-\right.\right. \\
\mathrm{TC})\} \\
\text { The trustee must choose the } \\
\text { most profitable alternative } \\
\text { for the estate; therefore, he } \\
\text { must prefer an alternative } \\
\text { transaction if it is expected } \\
\text { to yield a higher value, and } \\
\text { vice versa. }\end{array}$ \\
\hline
\end{tabular}

In the numerical example, if the trustee chooses to execute the contract, he would receive the balance due from the buyer and transfer the apartment to him after finishing the building. The liquidation fund will bear the costs of completing the building. In contrast, if the trustee avoids the contract, he would be able to sell the apartment to a new potential buyer. In this case, the trustee would need to find a new buyer and draft a new contract. In addition, the trustee would shoulder the burden of securing funds to complete the building. All of this may well be worth the trouble because, in many cases, the alternative transaction will yield a higher value to the estate than would the performance of the original contract.

The example illustrates that when deciding whether to perform an executory contract, the trustee cannot simply compare the balance due with the costs of completing the construction; rather, he must also take into account the price that he will be able to receive from selling the apartment to a third party. The trustee should only perform the contract when doing so will lead to a higher profit than can be obtained from the alternative transaction. Thus, for example, in a situation where prices of apartments are gradually declining, the trustee may find that performing the original contracts will be more beneficial. In contrast, in a situation where prices of apartments are rising, the more 
efficient alternative will usually be to cancel the existing contracts in favor of new transactions at higher prices. Of course, the original buyer can try to entice the trustee into performing the contract by showing a willingness to enlarge the balance due.

Finally, the trustee must consider that partaking in the alternative transaction will bind him to the costs that are entailed in the transaction. Therefore, the trustee's or the liquidator's willingness to perform the original contracts will also depend on the fluidity of the company's assets.

This legal arrangement implies that the commencement of bankruptcy proceedings entitles the trustee to the right to avoid onerous and unprofitable contracts. The law enables the trustee to free the estate from inefficient liabilities in ways that are not available outside the bankruptcy proceedings. The purpose of this legal arrangement is to facilitate the severance of economic resources from inefficient entitlements, so as to enable their return to productive business activity.

\section{CONCLUSION}

This Article shows that bankruptcy law can be understood as the legal solution to the phenomenon of inefficient entitlements. Firms initially engage in various contracts and liabilities based upon their expectations regarding future events. Nevertheless, reality may prove their expectations to be mistaken, and their contracts to be unprofitable. Generally, the law does not recognize lack of profitability as a justification for non-performance, and as a result, under certain circumstances, the unprofitable contracts may push these firms into inefficient activities and financial distress. Often, the parties would be able to settle such sources of inefficiency on their own, and enter into new contracts that would supplant the initial ones. Nevertheless, conflicts of interest may obstruct the renegotiation process, and therefore, some legal coercion may become essential for shifting the economic resources back to efficient activity. Bankruptcy law serves this essential role. It provides the legal process with substantive arrangements for severing the firm's resources from its inefficient entitlements. Legal arrangements such as the trustee's authority to obtain new credit in reorganization, secured creditors' entitlement to adequate protection, and the trustee's discretion to perform executory contracts are examples of the methods by which bankruptcy law enables the avoidance of existing entitlements. 